\title{
Konkurenceschopnost Evropské unie v podmínkách globalizace
}

\author{
Jana Sereghyová ${ }^{1}$
}

\begin{abstract}
Na jaře každého roku pořádá Hospodářská komise pro Evropu Spojených národů seminář, na kterém jsou diskutovány nejpalčivější sociálně-ekonomické problémy, doléhající v dané době na Evropu. Tentokrát se tento seminář (jenž se konal 23. a 24. února v Paláci národů $\mathrm{v}$ Ženevě) zabýval ekonomickým růstem a konkurenceschopností v evropském ECE regionu, jakož i podmínkami posílení jeho konkurenceschopnosti. Referáty zde přednesené renomovanými odborníky v tomto oboru (pp. K. Aigingerem z WIFO - Rakousko $^{2}$, J. Fagerbergem z university v Oslo, G. Horváthem z Mad’arskéakademie věd a K. Warwickem z ministerstva průmyslu a obchodu Velké Británie) se zabývaly řadou vysoce aktuálních otázek, které by bylo třeba co nejdříve vyjasnit. Zabývaly se např. otázkou, jaké charakteristiky by měl vykazovat nový model sociálně-ekonomického rozvoje Evropské unie, tak aby se mohl stát klíčem pro žádoucí posílení její konkurenceschopnosti; jaké jsou determinanty růstu konkurenceschopnosti v zemích, které přecházejí na „znalostně fundovaný“ typ ekonomického růstu; jaká je úloha státu při podporování růstu konkurenceschopnosti jeho podnikové sféry; jaké důsledky budou mít ohromné regionální rozdíly v konkurenceschopnosti dosud přetrvávající ve stř̌edo- a východoevropských transformačních zemích. Každý z těchto referátů se opíral o komparativní analýzy vývoje konkurenceschopnosti (meziregionální, mezistátní a v některých př́ípadech i mezikontinentální) a leckdy i o rozsáhlý „polní průzkum“ “. Ke každému z těchto témat bylo předneseno několik koreferátů zpracovaných též významnými ekonomy (např. pp. D. Daianu z Rumunska a P. Mertlíkem z ČR - oba bývalí ministři financí svých zemí). Bohatá diskuse proběhnuvší za účasti pléna se však zabývala nejen uvedenými problémovými okruhy, nýbrž i dalšími faktory, ovlivňujícími nadcházející vývoj konkurenceschopnosti členských států EU. Zabývala se např. otázkou, kterak za situace, kdy ve většině těchto států je třeba radikálně omezit rozpočtové schodky, bude možné zde navýšit „investice do budoucnosti“ natolik, aby jim umožnily obhájit či dokonce posílit jejich pozice v konkurenci s jinými zralými tržními ekonomikami. Bylo poukázáno též na fundamentální změny v konkurenčním prostředí, v němž budou nadále operovat hospodářské organizace členských států EU, které byly navozené globalizací světové ekonomiky, jakož i na naléhavou potřebu tyto změny zohlednit nejen př̌i koncipování podnikatelských strategií, nýbrž i hospodářsko-politických opatření cílených na posílení jejich konkurenceschopnosti.
\end{abstract}

Tato stat si klade za cíl seznámit naši akademickou obec s nejdůležitějšími novými poznatky prezentovanými na uvedeném semináři a upozornit ji též na diskuse zabývající se

1 Dr. Jana Sereghyová, DrSc., Institut integrace ČR do evropské a světové ekonomiky Fakulty mezinárodních vztahů Vysoké školy ekonomické v Praze.

2 Österreichisches Institut für Wirschaftsforschung.

3 Nejdůležitější z těchto komparativních statistických podkladů budou zanedlouho publikovány na internetových stránkách IČRE. 
některými teoretickými otázkami konkurenceschopnosti, probíhající na stránkách zahraničního odborného tisku. Obsahuje též první výsledky našeho vlastního výzkumu, zaměřeného na objasnění předpokladů pro růst konkurenceschopnosti v podmínkách globalizace světové ekonomiky.

\section{Některé z nejdiskutovanějších teoretických otázek}

Již od počátku 90. let je živě diskutována otázka, je-li správné hovořit o konkurenceschopnosti států, nemohou-li vykazovat tuto schopnost pouze hospodářské subjekty (tak jak zdůrazňoval Paul Krugman ve svém díle publikovaném v roce $1994^{4}$ ). Dnes se shoduje naprostá většina ekonomů v názoru, že existuje konkurenceschopnost jak na mikroekonomické, tak na makroekonomické úrovni. Druhá byla již v roce 1992 definována na půdě $\mathrm{OECD}^{5}$,,jako způsobilost země produkovat v podmínkách otevřené tržní ekonomiky výrobky a služby, které obstojí $\mathrm{v}$ zahraniční konkurenci, a zachovat či rozšiřovat současně i reálný hrubý domácí produkt". Z později publikovaných definic uvádíme zde jen tu, která vzešla z jednoho z nejprestižnějších výzkumných pracovištzabývajících se touto problematikou, tj. z Cambridgské university ${ }^{6}$, která charakterizovala konkurenceschopnost země „jako její schopnost dosahovat trvale taková tempa ekonomického růstu, která se shodují v hrubých rysech s tempy růstu zemí, které jsou jejími hlavními obchodními partnery“. Zatímco prvá $\mathrm{z}$ uvedených definic připouštěla, aby konkurenceschopnost té které země byla hodnocena převážně jen v historické retrospektivě, vystupuje $\mathrm{v}$ druhé $\mathrm{z}$ nich již do popředí požadavek, aby byla hodnocena především v mezinárodní komparaci. Konkurenceschopnost jednotlivých zemí a regionů se tudíž nadále chápe jako relativní veličina, kterou je třeba stále znovu porovnávat s vývojem konkurenceschopností dalších zemí a regionů.

Tomu odpovídá i selekce dnes uplatňovaných kritérií konkurenceschopnosti. Za klíčová kritéria konkurenceschopnosti jednotlivých zemí jsou dnes považovány jednak proměny jejich tržních podílů, jednak i jimi dosahovaná tempa ekonomického růstu. ${ }^{7}$ Druhé však není sledováno na základě proměn absolutní výše jejich HDP, nýbrž na základě vývoje jejich HDP per capita, což je považováno za záruku toho, že postihuje nejen ekonomické, nýbrž i sociální aspekty vývoje konkurenceschopnosti, resp. jejím posilováním navozený růst př́ijmů a životní úrovně obyvatelstva. Jde zde o značně diskusní presumpci, nebot̉ nedávno dovršené výsledky výzkumu prokázaly, že - nezávisle na dramatickém růstu HDP per capita zaznamenaném v některých „mladých ekonomikách“ - nenarůstá zde prosperita obyvatelstva (a leckde jeho životní úroveň dokonce klesá). Narůstá tak potřeba zařadit mezi kritéria konkurenceschopnosti zemí i taková, která zachycují dynamiku růstu zdejší soukromé spotřeby, popř. i jiné ukazatele vývoje životní úrovně obyvatelstva.

$\mathrm{K}$ tomu však dochází prozatím jen $\mathrm{v}$ ojedinělých případech, zatímco spektrum dnes používaných hodnotících kritérií bylo rozšířeno o desítky takových, která se - na základě expertních posudků - pokouší charakterizovat podnikatelské prostředí vyvíjející se v dané zemi. K tomuto obohacení přísl. databáze (o více než stovku tzv. „měkkých indikátorü“) došlo s odůvodněním, že toto prostředí předurčuje budoucí vývoj konkurenceschopnosti

4 Viz Krugman, P.: „Competitiveness, a dangerous obsession“. Foreign Affairs No. 73, 1994.

5 Viz „Technology and the economy: the key relationships.“ Paris, OECD, 1992.

6 Viz Aghion Ph. - Howit, P.: „Endogenous growth theory“. Cambridge, MIT Press, 1998

7 Je pozoruhodné, že prvé z uvedených klíčových kritérií nebývá zahrnováno mezi ta, na jejichž základě je konkurenceschopnost zemí hodnocena ve „World competitiveness report“ i v dalších publikacích předkládajících „rating“ konkurenceschopnosti jednotlivých zemí. 
té které země, že umožňuje identifikovat „nežádoucí jevy“ a současně s tím i selekci „nápravných opatření“. Ve skutečnosti slouží tato přehršle nově uplatňovaných kritérií hlavně vyjasnění potenciálních přínosů a rizik, která by doléhala na ty zahraniční investory, kteří by se odhodlali investovat $\mathrm{v}$ té které zemi, jakož i identifikaci opatření, která by činila jejich aktivity v dané zemi bezpečnějšími a výnosnějšími. Iv této podobě plní dodatečné uplatnění těchto hodnotících kritérií důležitou funkci. Je jen třeba, aby si ekonomové a národohospodáři uvědomili, čeho se týče jejich výpovědischopnost.

Relativně nejdéle a nejživěji diskutovaným teoretickým problémem však zůstává i nadále určení charakteru dominantního typu mezinárodní konkurence, nebot̉ ten předurčuje opatření a strategii, která by mohla napomáhat posílení konkurenceschopnosti jak zemí, tak jejich hospodářských organizací. Tato diskuse probíhá již od konce 19. století, kdy zejména americkými ekonomy byla obhajována teze, že zánik tzv. „dokonalé konkurence“ by vedl k zániku konkurence jakožto takové a současně s tím i k útlumu podnikatelské iniciativy i ekonomického růstu. Avšak v dílech evropských (zejména keynsiánsky zaměřených) ekonomů bylo již počátkem 30. let zdůrazňováno, že postupný zánik „,dokonalé konkurence“ nevede k zániku konkurenčního zápolení, nýbrž pouze ke změně jeho charakteristik. Prokázali, že se vznikem a rozšîřením „záběru“ oligopolních a monopolních trhů došlo ke vzniku tzv. „nedokonalé konkurence“, kterou později nazvali „monopolistickou konkurencí“ (přestože výskyt tohoto typu konkurence byl prokázán jak na monopolních, tak i na oligopolních trzích). ${ }^{8}$

Nezávisle na tomto vyjasnění situace vycházeli jak teoretici, tak národohospodáři při zvažování cest ke zvyšování konkurenceschopnosti jednotlivých zemí ještě desítky let z učebnicové představy převažující existence dokonalých trhů a „dokonalé konkurence“. Ta bazíruje jak známo na premise, že všechny hospodářské subjekty mají přístup ke stejně velkému rozsahu informací a znalostí a že vyrábějí výrobky vykazující identickou kvalitu, že tudíž hlavním (a leckde jediným) jimi použitelným nástrojem konkurence je jejich cenová konkurenceschopnost. Opatření sloužící k posílení konkurenceschopnosti byla v té době tudíž zaměřena převážně jen na snižování výrobních nákladů podmiňující snižování cen výrobků, zatímco opomíjela jiná, ve změněné situaci pro posílení konkurenceschopnosti daleko důležitější opatření. Na zcestnost tohoto postupu upozornil Joseph Schumpeter již počátkem 40.let ${ }^{9}$, kdy poukázal na to, že (již tehdy) se ekonomická realita výrazně lišila od tohoto učebnicového modelu (dokonalé) konkurence. Zdůrazňoval, ${ }^{10}$ že v rozvinutém kapitalistickém světovém hospodářství nereprezentují cenové ústupky, na které mohou přistoupit někteří z tradičních výrobců individuálních druhů zboží (pouze zvýšením produktivity práce při zachování stávajících organizačních principů a technologií), zdaleka nejzávažnější hrozbu pro ostatní podniky operující na témže (zbožovém) trhu; že v těchto podmínkách to bývají hlavně meritorní nákladová či kvalitativní konkurenční zvýhodnění, dosažená některým z podniků (již operujících či nově pronikajících na daný trh) díky využití nových technologií, nových zdrojů, či nových organizačních principů, co zakládá stěžejní konkurenční hrozbu, nebot ta nedoléhá již jen na rozsah ziskových marží či odbytových možností ostatních podniků operujících na daném trhu, nýbrž ohrožuje jejich samotnou existenci.

V následných desetiletích bylo těmto novým stereotypům - resp. změněnému prostředí, v němž se nadále odvijí mezinárodní konkurence - věnována zvýšená pozornost jak

\footnotetext{
8 Viz Robinson, J.: „The economics of imperfect competition“. London, 1963, a Chamberlin, E. H., Robinson, J.: „The theory of monopolistic competition“. Harvard University Press, 1933.

9 Viz J. Schumpeter: „Captitalism, Socialism and Democracy“. Harper, N.Y. 1943.

10 Jde o „volnou“ interpretaci textu obsaženého v díle tohoto autora.
} 
v rámci teorie mezinárodního obchodu, tak institucionální teorie. Diskutovány byly hlavně kauzální vazby stojící za změnami v obsahu a směrování mezinárodních toků zboží, jakož i důsledky urychlené mezinárodní koncentrace kapitálu a dominantního postavení, které v mezinárodních hospodářských vztazích získaly multinacionální korporace. Třebaže hodnocení těchto dvou procesů se případ od případu liší, shodují se dnes teoretici zabývající se těmito dvěma vědními disciplínami v názoru, že nastala éra „aliančního kapitalismu“, která dodává i charakteristice mezinárodní konkurence některé nové rysy.

Ještě donedávna převažoval názor, že v této nové éře, kdy dříve si vzájemně tvrdě konkurující multinacionální korporace vytvářejí strategické aliance sloužící jako báze pro jejich společný postup na různých úsecích jejich aktivity (nejen v oblasti výzkumu a vývoje, jak bývá zpravidla deklarováno) a jako platforma, na níž se řeší eventuální vznik jejich vzájemných rozporů „mimotržní cestou“, dojde k oslabení mezinárodní konkurence. Vývoj předchozího desetiletí však signalizuje, že pravý opak je pravdou. Tomu nasvědčuje nejen tzv. „merger-mánie“ zachvátivší v té době svět, která je provázená nebývale početným výskytem tzv. „nepřátelských převzetí“ („vicious take-overs“), nýbrž i překvapivé oživení tzv. „Zabijácké konkurence“ („cut-throat competition“), která byla jednou ze stěžejních konkurenčních metod uplatňovaných v dobách dokonalé konkurence. Nasvědčují tomu též nové organizační principy uplatňované v rámci mezinárodních podnikatelských sítí, jakož i radikální změny ve funkčních stereotypech podniků, operujících na tzv. „zajatých trzích“ (captive markets).

Začíná se zde již zřetelně rýsovat, že tak jako vznik monopolních trhů nevedl k zániku mezinárodní konkurence, nýbrž ke vzniku konkurence nového typu, ani vznik ,aliančního kapitalismu“ nevyústí v nahrazení konkurenčního zápolení předem dohodnutým společným postupem multinacionálních korporací sdružených ve strategických aliancích, nýbrž povede ke vzniku nového typu konkurenčního zápolení, ke vzniku tzv. ,globalistické konkurence“". Jde zde o nový jev, jenž je zkoumán v rámci výše uvedených dvou vědních disciplin, i v rámci teorie konkurence teprve velice krátkou dobu. Povědomí jeho závažnosti se však již stalo podnětem pro svolání četných mohutných diskusních fór (realizovaných nejen na akademické půdě, nýbrž nezřídka i na půdě mezinárodních organizací), ${ }^{12}$ na nichž jsou tvrdě diskutována jak zjištění týkající se jeho funkčních stereotypů, tak představy teoretiků o jeho možných účincích a důsledcích. Jde prozatím o kusé poznatky, které ještě neumožňují sestavit komplexní nárys konkurenčního prostředí, v němž budou operovat země a jejich hospodářské subjekty v dalších fázích tohoto století. Lze však z nich vyvozovat, že $\mathrm{v}$ dlouhodobém - a leckde již ve střednědobém - horizontu dojde k meritorním změnám ve světové topografii hospodářských aktivit, které budou provázeny nebývalým zesílením konkurenčních tlaků, jimž budou vystaveny jak země, tak hospodářské organizace, které se patřičně nepřipraví na tuto novou situaci, anebo nejsou s to ji zvládnout z jiných důvodů.

11 Podrobněji viz: J. Sereghyová, Sch. Zafarpour: „Topical issues of international corporate networking in the globalising world economy“. Wirtschafsuniversität Wien, 2004.

12 Viz Jarní seminář Hospodářské komise pro Evropu OSN (únor 2004) zabývající se „Competitiveness and economic growth in the UNECE Region“ anebo „Executive forum on competing in a changing Europe“ pořádané pod egidou Organizace spojených národů v květnu téhož roku. Na všech těchto fórech byly prezentovány a diskutovány též výsledky výzkumu prováděného na půdě IČRE/VŠE. 


\section{Faktory vyvolávající nové charakteristiky konkurenčního prostředí}

Faktory vedoucí k uvedeným změnám v konkurenčním prostředí jsou jak obchodně-politické a finanční, tak i technologické povahy, přičemž předěl mezi původní situací a dobou, kdy konkurenční prostředí vykazuje nové charakteristiky, nezřídka splývá.

Pro ilustraci toho postačí připomenout, že liberalizace mezinárodního obchodu ${ }^{13}$ probíhala již od padesátých let se zvýšenou razancí, takže v době ukončení tzv. „Uruquayského kola" GATTu ${ }^{14}$ byla v obchodě mezi členskými státy této mezinárodní organizace odstraněna valná část kvantitativních bariér dovozu průmyslových výrobkủ ${ }^{15}$ a byla radikálně snížena i cla ${ }^{16}$,jimž podléhal jejich vzájemný obchod těmito výrobky. Již od počátků 80. let tak byli výrobci naprosté většiny prủmyslových výrobků vystaveni tvrdým konkurenčním tlakům, a to nejen na zahraničních trzích, nýbrž i na jejich domácím trhu, kam měla zahraniční konkurence nadále volný přístup. Dopady této skutečnosti na jejich perspektivy však byly i nadále do jisté míry tlumeny jednak tzv. „dopravními inhibicemi““ ${ }^{17}$ (které nezř́ílka vedly $\mathrm{k}$ preferencím domácích dodavatelů před vzdálenými zahraničními dodavateli ${ }^{18}$ ), jednak i širokým okruhem vnitrostátně platných technických norem a předpisů, které podvazovaly dovoz výrobků, které těmto normám (fakticky či z formálních důvodů) neodpovídaly. Jako ochranný mechanismus působila též omezená dostupnost informací o potenciálních zahraničních dodavatelích přísl. výrobků. Ta totiž chránila dobře známé, nejen na jejich domácích, nýbrž i na zahraničních trzích již „etablované“ podniky, před konkurenčními tlaky „nových“ neznámých dodavatelů daného druhu zboží.

Konkurenci omezující účinky uvedených norem sice trvají i nadále. Skutečnost, že bývají unifikovány v rámci jednotlivých integračních seskupeních (např. v rámci Evropské unie, v rámci NAFTA), anebo dokonce $\mathrm{v}$ rámci celých průmyslových oborů (viz CENELEC a jiné), však omezuje jejich účinky. Chrání vnitřní trh jednotlivých zemí již jen proti konkurenčním tlakům podniků se sídlem v tzv. „třetích zemích“, jakož i vůči dodavatelům, kteří nejsou členy uvedených oborových dohod.

I dopravní inhibice se začínaly již od poloviny 80 . let postupně omezovat. Přispěl $\mathrm{k}$ tomu v prvé fázi hlavně radikální pokles světové ceny ropy a následně i nákladů námořní dopravy, $\mathrm{k}$ němuž došlo bezprostředně po ukončení světové energetické krize. ${ }^{19}$ Tyto náklady tudíž figurují nadále mezi zábranami vstupu na vzdálené trhy jen tehdy, je-li předmě-

13 Liberalizace se však prozatím netýká obchodu zemědělskými produkty a mnohými potravinářskými výrobky. Dosud se nevztahovala ani na obchod textilem a oděvy i některými dalšími druhy spotřebního zboží denního užití.

14 V současné době má následnická organizace GATTu, tj. WTO (Světová obchodní organizace) 144 členů. Jejími členy jsou všechny „zralé“ tržní ekonomiky a většina rozvojových i část transformačních zemí.

15 Pouze v obchodě textilním zbožím byly v těchto státech i nadále uplatňovány množstevní zábrany dovozu. Ty by však měly být ve styku mezi členskými státy WTO odstraněny do konce roku 2004, kdy končí platnost tzv. „multifibre agreement", jež uplatnění těchto množstevních omezení připouštělo. Budou oprávněny uplatňovat je nadále pouze vǔči Č́ině a samozřejmě i vǔči nečlenským státům WTO.

$16 \mathrm{~V}$ průměru na $10 \%$ úrovně vžité ještě koncem 40 . let.

17 Tj. zábranám dopravování výrobků na větší vzdálenosti dané výší nákladů a rizik, souvisejících s jejich dopravou (resp. vysokým podílem těchto nákladů na souhrnu jejich kalkulačních položek).

18 Tyto preference však byly dány nejen dř́ve relativně vysokými dopravními náklady, nýbrž i zvýhodněným reglementem, jemuž podléhá obchod těmito výrobky probíhající uvnitř integračních seskupení).

19 Dopravní inhibice v obchodě surovinami a jinými dopravně vysoce náročnými produkty pocházejícími z „nízkoziskových výrob“, však trvají i nadále.. Vedla ke vzniku přísně limitovaných regionálních trhů, v jejichž rámci se intensita konkurenčního zápolení, jakož i vývoj cenových hladin mnohdy výrazně liší. 
tem obchodu velice levné, současně však dopravně vysoce náročné zboží. Později se omezovaly dopravní inhibice též v důsledku přívětivých stanovisek, které vlády většiny rozvojových i transformačních zemí zaujaly $\mathrm{k}$ přímým zahraničním investicím (i v důsledku urychleného otevírání kapitálových trhủ mnohých z těchto zemí). To totiž umožnilo multinacionálním korporacím zakládat své výrobní afilace v bezprostřední blízkosti svých zdejších odbytišša nadobro se tak zhostit důsledků dopravní inhibice. Ta tudíž omezuje nadále okruh zahraničních odbytišt̉en těch výrobců dopravně náročnějších výrobků, kteří se $\mathrm{k}$ takovému přenesení některých svých provozů do zahraničí dosud neodhodlali.

Legislativně a finančně daná možnost jednotlivých hospodářských subjektů zakládat afilace v zahraničí není ovšem nic nového. Rozšiřovala se pod vlivem Mezinárodního měnového fondu a WTO po celé poválečné období. Byla to však teprve technologicky daná možnost dělit většinu výrobních procesů na samostatně provozovatelné dílčí výroby (na výrobní segmenty), plně se rozvinuvš́ teprve v 80. a 90. letech, co otevřelo cestu k mohutnému rozmachu tzv. internacionální výroby. ${ }^{20} \mathrm{~A}$ ta změnila mezinárodní konkurenční prostř̌edí i charakteristiky konkurenčního zápolení naprosto zásadním způsobem. Umožňuje totiž jednotlivým podnikům (korporacím) rozmístit každý z těchto segmentů do zemí a regionů, kde danou výrobu lze zabezpečit nejlépe a současně i nejlevněji. Podnik, jenž organizuje tímto způsobem svou mezinárodní výrobní sít, tak získává možnost tě̌̌it z komparativních výhod všech těch zemí, kam rozmístil své afilace. To mu dopomáhá k mohutnému konkurenčnímu zvýhodnění, jehož důsledkům nemůže čelit ani jeden z jeho konkurentů, jenž takovou segmentaci a mezinárodní dislokaci své výroby neprovádí.

To platí též o podnicích se sídlem v zemích, kde pracovní náklady se dosud udržují na silně subnormální úrovni, nebot jejich možnost uplatnit (resp. realizovat) v mezinárodním obchodě tuto svou komparativní výhodu je podmíněna tím, že jejich výrobky nesou věhlasnou výrobní či obchodní značku a že budou mít přístup do mezinárodních distribučních sítí, jimiž proudí značkové zboží. A tyto dva předpoklady prozatím stačí domácí podniky se sídlem v „mladých ekonomikách“ zabezpečit jen zřídkakdy tím, že by vybudovaly vlastní mohutnou mezinárodní podnikatelskou (a distribuční) sít t1 $^{2}$. Daleko častěji bývají odkázány na to zapojit se do takovéto sítě operované některou z multinacionálních korporací. V tom př́ípadě to však bývá tato korporace, která realizuje převážnou část uvedeného kalkulačního zvýhodnění těchto podniků. Hlavní přínos takového jejich zapojení do mezinárodních podnikatelských struktur tak spočívá pouze ve zlepšení jejich „šancí na př̌ežiti““ v nebývale zostřeném mezinárodním konkurenčním zápolení.

V minulosti byl okruh zemí a regionů, kam bylo lze přemístit technologicky náročnější výroby, přísně omezen tím, že jejich zdar byl podmíněn existencí kvalifikovaných pracovních sil v dané lokalitě. V posledních dvou desetiletích vyvinutá (technická i organizační) zjednodušení většiny takovýchto výrobních procesů (jakož i zautomatizování kvalitativní kontroly jejich „výstupư“) však nadále umožňuje - bez rizika opakujících se kvalitativních závad - provozovat řadu těchto výrob či některé jejich technologicky méně náročné segmenty prakticky v kterékoli zemi, kde obyvatelstvo je s to osvojit si alespoň základní pracovní disciplínu (mnohdy to ani nevyžaduje, aby bylo gramotné). Nebývalou měrou se tak rozšiřuje možný územní rozptyl mezinárodních podnikatelských sítí zakládaných tradičními provozovateli technologicky náročných výrob. Umožní jim to rozšiřovat nadále svou subdodavatelskou základnu eventuálně i do hospodářsky velice málo vyvinutých rozvojových zemí, kde mzdové hladiny bývají řádově nižší než v plně industrializovaných zemích, kam své subdodavatelské provozy rozmistovaly ještě v nedávné minulosti. To zabezpečuje

20 Tj. výroba jejíž dílčí úseky se realizují v různých zemích. Podrobněji viz Dunning, J. H.: International Production and the Multinational Entertprise“. London, Allen + Unwin, 1981.

21 To se dosud podařilo jen v některých nově industrializovaných zemích jihovýchodní Asie. 
multinacionálním korporacím operujícím takovéto důsledně globalizované podnikatelské sítě ohromné kalkulační výhody ${ }^{22}$ a současně i nenapadnutelnou převahu v konkurenčním zápolení s podniky, které takovýto globalistický přístup k mezinárodní dislokaci své výroby neuplatňuji. ${ }^{23}$ Jde o další významný faktor měnící konkurenční prostředí, v němž se budou muset uplatnit i naše podniky.

Hluboký zásah do vžité podoby tohoto prostředí vyvolal též vznik tzv. globálního sourcingu (,global sourcing system“). I on se opírá o technologickou inovaci, o elektronizaci komunikačních systémů, přesněji řečeno, o napojení vzrůstajícího počtu hospodářských subjektů na internet. Dokud toto napojení nebylo vžité, adresovali podnikatelé zainteresovaní na zakoupení průmyslových výrobků či polotovarů své poptávky omezenému okruhu jim známých potenciálních dodavatelů (známých z veletrhů, výstav a reklamy i takovým, kteří v daném regionu již získali dobrou pověst). V současné době, kdy většina poptávek bývá zveřejněná na internetu, slouží de facto jako výzva adresovaná všem potenciálním dodavatelům daného druhu zboží, at již mají své sídlo v kterékoli zemi světa, aby se zúčastnili na konkurenčním zápolení o získání dané zakázky. Zkušenosti svědčí o tom, že na jedné straně tím dané ohromné zvýšení počtu podniků podílejících se na takovémto konkurenčním zápolení, na druhé straně pak skutečnost, že mezi nimi nadále figurují též podniky se sídlem v zemích, kde dosud přetrvávají silně subnormální pracovní náklady, významně přispěla ke snížení cen, za které ti odběratelé těchto výrobků, kteří důsledně uplatňují systém globálního sourcingu, realizují své nákupy v zahraničí. Kalkulační zvýhodnění těchto podniků - jimi uplatňované v mezinárodní konkurenci - se tím dále zvyšuje.

Někteří autoři poukazují na to, že zavedení systému globálního sourcingu přineslo i dosud neznámým výrobcům (se sídlem v rozvojových či transformačních zemích) nemalé výhody. Ty jsou spatřovány hlavně $\mathrm{v}$ tom, že jim zabezpečil minimálně nákladnou ${ }^{24}$ příležitost prezentovat se svým potenciálním zahraničním odběratelům, že reprezentuje jednu z mála jim dostupných možností, jak uspět v konkurenci s renomovanými dodavateli, již etablovanými na odbytištích jimi produkovaných druhů zboží. Tuto možnost však budou mít jen tehdy, stačí-li si včas osvojit všechny usance vžité v obchodě (a při užití) daného druhu zboží a postoupí-li svým odběratelům převážnou část svých kalkulačních zvýhodnění, daných příznivějšími operačními podmínkami v zemi jejich sídla. To bývá odběrateli považováno za nezbytnou kompenzaci jejich ochoty vzít na sebe rizika, související s využitím dodávek výrobce, jehož smluvní a kvalitativní disciplína ještě nebyla testována desítkami či stovkami jeho předchozích zahraničních odběratelů. Většina těchto výrobců však považuje tuto cesi svých kalkulačních výhod za důsledek slabé pozice, kterou zaujímají v negociaci s mohutnými multinacionálními korporacemi, o jejíž upevnění se míní pokoušet.

22 Postačí připomenout, že „pracovní náklady“ s nimiž musejí počítat mohutné afilace multinacionálních korporací založené v posledních třech letech ve vnitrozemí Číny, odpovídají zhruba jedné třicetině pracovních nákladů, s nimiž musejí počítat jejich afilace situované ve zralých tržních ekonomikách. Přitom výroba probíhající v jejich čínských afilacích využívá progresivní technologie vyvinuté těmito korporacemi, jejich zde produkované výrobky vykazují dokonalou kvalitu a nesou -zcela legálně- též světoznámé výrobní či obchodní značky. Zpravidla bývají též obchodovány prostřednictvím distribuční sítě dané „mateřské společnosti“. To vše umožňuje za tyto výrobky dosahovat téměř stejné ceny, jako za výrobky (či polotovary) produkované touto společností ve vlastních „kmenových“provozech anebo v jejich afilacích situovaných v hospodářsky vyspělých zemích.

23 Rozdíly v př́istupu jejich podnikové sféry k uplatňování takovýchto globalistických principů mezinárodní dislokace jejich průmyslových výrob bývají též považovány za jeden z důležitých důvodů pro dosud přetrvávající rozdíly v konkurenceschopnosti tř́i členů „triády“.

24 Alternativou je dlouholeté pořádání celoplošných reklamních kampaní a opakované účasti na výstavách a veletrzích, tzn. mimořádně nákladné akce, které „noví výrobci“ se sídlem v rozvojových či transformačních zemích mnohdy nestačí financovat. 


\section{Názory na makroekonomické efekty uplatňování globalistic- kých konkurenčních metod}

Vycházíme-li z všeobecně uznávané teze, že „konkurenceschopnost států je dána konkurenceschopností jejich hospodářských subjektư “25, dalo by se očekávat, že masové uplatňování výše popsaných globalistických konkurenčních praktik, které zabezpečují hospodářským subjektům, které je uplatňují, nemalé přínosy, bude mít v zemích jejich sídla vesměs velice pozitivní makroekonomické účinky. Hospodářská realita však svědčí o tom, že tomu tak není ve všech případech, přičemž některé z těchto praktik zde mívají naopak závažné negativní zpětné vazby. Jak názory na závažnost těchto zpětných vazeb, tak na jejich př́činy se však dosud liší. Pro ilustraci předkládáme nárys nejdůležitějších z nich:

Z předchozího výkladu vyplynulo, že dnes rychle se rozmáhající přenášení pracovně velice náročných výrob ze zralých tržních ekonomik do hospodářsky méně vyspělých zemí $i$ masové uplatňování globálního sourcingu vede k urychlenému zapojování těchto zemí do mezinárodní dělby práce probíhající dnes $\mathrm{v}$ průmyslu již v celosvětovém měřítku; že jim dopomáhá k technologickému know-how (a nezrrídka i k investicím), které by si zpravidla nestačily zabezpečit samy; že nejméně vyspělým (dosud převážně agrárním) rozvojovým zemím dopomáhá $\mathrm{k}$ urychlení jejich industrializace (jîž by se jinak patrně nedočkaly ještě desítky let); že se tak vytvářív těchto zemích předpoklady pro omezování zde chronicky vysoké míry nezaměstnanosti i pro umírnění chudoby. Za zvláště významné je považována skutečnost, že pod vlivem uvedených globalistických mechanismů vzniká v mnohých z těchto zemí subdodavatelská základna sloužící mohutným multinacionálním korporacím provozujícím výzkumně vysoce náročné výroby. V tom je spatřována ojedinělá možnost zvyšovat kvalifikaci jejich obyvatelstva, která by se postupem doby mohla stát klíčem k zapojení těchto zemí do technologicky náročnějších, výnosnějších výrob; která by jim umožnila již vbrzku zařadit se mezi rychle rostoucí nově industrializované země.

Někteří z ekonomů, pocházejících z těchto zemí, však poukazují na to, že industrializace probíhající z podnětu a „pod kuratelou“ multinacionálních korporací neskýtá příznivé předpoklady pro vytvoření komplexních, dlouhodobým zájmům rozvojových zemí vyhovujících průmyslových struktur. Bývá též spojena s nemalými riziky danými jednak tím, že v těchto zemích bývají dosud zakládány vesměs nezakotvené („footloose“) výroby, které bývají přenášeny ze země do země (podle proměn v hladině zdejších mezd či směnného kurzu jejich měn), jednak tím, že tento typ industrializace je činí závislými na jejich odběratelích, což je údajně dává „na pospas“ jimi uplatňovaným nátlakovým prostředkủm.

Uplatňování nátlakových prostředků bývá připisována též skutečnost, že ceny placené multinacionálními korporacemi svým dodavatelům a subdodavatelům se sídlem v hospodářsky méně vyspělých zemích bývají natolik nízké, že mnohdy nepřipouštějí vyplácení mezd převyšujících zdejší „životní minimum“, tím méně pak rozšiřování či modernizaci domácích podniků; že tudíž nevytváří podněty ani pro rozvoj investiční aktivity těchto podniků, ani pro růst zdejší soukromé spotřeby. Proti této kritice bývá namítáno, že tlak multinacionálních korporací na podmínky, za nichž realizují své obchody v rozvojových zemích, reprezentuje pouze jednu, a to zcela podružnou př́činu subnormální úrovně cen jimi placených za zde realizované nákupy; že její hlavní příčina spočívá v dravém vzájemném konkurenčním zápolení zdejších podniků, $\mathrm{v}$ němž každý z nich se pokouší o získání dané zakázky, kooperačního zadání či investice pomocí cenových ústupků stlačujících jeho vý-

25 Viz např. J. Fagerberg: „International competitiveness“. Economic Journal 98/1988.

26 Ekonomická historie nově industrializovaných zemí jihovýchodní Asie je důkazem toho, že takovýto posun je možný. Je jen otázkou, v jaké míře je tento jev opakovatelný v rychle se globalizující světové ekonomice. 
nosy z dané operace až na samou hranici únosnosti. Někteří autoři však připisují tuto situaci hlavně chronické nadprodukci většiny „pracovně náročných, technologicky však nenáročných" výrobků, která narušuje stále znovu tržní rovnováhu v jejich mezinárodním obchodě a tlačí permanentně na hladinu za ně dosažitelných cen.

Nezávisle na tom, který z uvedených vlivů mívá za následek, že prodejní ceny dosahované domácími podniky se sídlem v hospodářsky méně vyspělých zemích za jimi produkované výrobky či polotovary se pohybují trvale $\mathrm{v}$ bezprostřední blízkosti jejich značně nízkého „konkurenčního prahu“" ${ }^{27}$, nasvědčuje tato skutečnost oprávněnosti teze obhajované některými věhlasnými teoretiky ${ }^{28}$, že touto cestou dochází permanentně $\mathrm{k}$ odčerpávání nemalé části v těchto zemích vytvářené „přidané hodnoty“ do zahraničí. Zbývá ještě vyjasnit, zda k této redistribuci hodnot dochází ve prospěch hospodářsky vyspělých partnerských států, anebo ve prospěch těch jejich hospodářských subjektů, kteří výše popsané globalistické konkurenční praktiky uplatňují.

Druhé z uvedených alternativ nasvědčuje zjištění, že z kalkulačního zvýhodnění a tím daného posílení konkurenceschopnosti multinacionálních korporací „profituji“ země jejich sídla (či původu) jen tehdy, daní-li zde své zisky - zvýšené touto cestou - a vede-li tím dosažené posílení jejich pozic v mezinárodním obchodě ke zvýšení počtu jejich „domácích“ zaměstnancủ. Námi zpracované príípadové studie svědčí o tom, že tomu tak bývá jen zřídkakdy, že podíl domácích zaměstnanců na celkovém osazenstvu multinacionálních korporací pod vlivem rychle postupující globalizace jejich podnikatelských sítí i nadále klesá, přičemž v multinacionálních korporacích, které mají své hlavní sídlo v malých zemích, se pohybuje tento podíl většinou jen mezi 1 a $3 \%{ }^{29}$. Zjistili jsme kromě toho, že legislativa USA a Japonska podvazuje možnosti zde zakotvených multinacionálních korporací danit své zisky v cizině (i tehdy, pocházejí-li z aktivit jimi zabezpečovaných v zahraničí), že však multinacionální korporace se sídlem v naprosté většině ostatních zralých tržních ekonomik běžně využívají ustanovení dohod o zamezení dvojího zdanění (uzavíraných pod egidou WTO i dalších mezinárodních organizací) $\mathrm{k}$ tomu, aby zcela regulérním způsobem ${ }^{30}$ plnily své fiskální povinnosti v těch zemích, kde podnikatelské daně jsou relativně nejnižší, a to bývá jen málokdy v zemi jejich hlavního sídla. ${ }^{31} \mathrm{~S}$ přihlédnutím k hojnému uplatňování takovýchto, zcela legálních, úhybných daňových manévrů se stává lépe pochopitelným, proč ve dvou největších členských státech Unie, které jsou nejen zemí původu, nýbrž i hlavním sídlem řady nejúspěšnějších multinacionálních korporací světa, se ocitly veřejné finance v poslední době v nesnázích.

27 „Konkurenční práh“ je dán jednak úrovní výrobních nákladů, se kterou musí daný podnikatel počítat při zabezpečováníjim reálně prováděných aktivit, jednak mírou zisku dosažitelnou v jiném oboru či odvětví, kde by se mohl uplatnit, pakliže by v dané výrobě neuspěl. Konkurenční práh podnikatelů v nejméně vyspělých rozvojových zemích bývá mimořádně nízký nejen proto, že využívají zde vžitou subnormální hladinu mezd a pracovních nákladů, nýbrž i proto, že jediná alternativní možnost jejich uplatnění bývá zpravidla v oblasti zemědělství, kde míra zisku bývá extrémně nízká. Podrobněji viz: Sereghyová J.: „Konkurencia és koordináció a világpiacon“ Közgazdasági és jogi Könyvkiadó". Budapest, 1974.

28 Viz: např.: L. K. Mytelka, Maastricht UN University, J. Chlumský, VŠE Praha aj.

29 To platí jak o firmě Nestlé, tak i o firmě Nokia. Platí to však i o multinacionálních korporacích které mají své sídlo v Belgií a Holandsku. V prvých náznacích lze pozorovat tento trend též u multinacionálních korporací se sídlem v Rakousku a Švédsku.

30 Tzn. aniž by prováděly „šedé transakce“ umožňující jim danit zisky v tzv. „daňových rájích“ (,tax-haven-countries“).

31 Mezi členskými státy EU/15 se vyskytují pouze dvě země, (Lucembursko a Irsko) kde hladina podnikatelských daní je srovnatelná s tou, která je vžitá v mnohých rozvojových zemích. 
Představitelé odborových organizací i mnozí evropští národohospodáři se shodují v názoru, že masové přenášení pracovně náročných, technologicky však nenáročných výrob do hospodářsky méně vyspělých zemí, jež se rozmohlo zejména v průběhu 90 . let, může vyvolat ve zralých tržních ekonomikách nemalé makroekonomické problémy. Podvazuje zde totiž růst - anebo vede dokonce k rozsáhlým ztrátám - pracovních př́ležitostí, které lze obsazovat méně kvalifikovanou částí jejich obyvatelstva. Poukazují na to, že konjunkturní výkyvy i „vnější ekonomické šoky“ tak doléhají na tuto skupinu zdejších pracujících podstatně tvrději než v minulosti, což by mohlo v řadě zemí vést dokonce $\mathrm{k}$ petrifikaci nepříznivé situace na jejich trhu práce. Oprávněnost těchto obav se potvrdila během recese, která zachvátila světovou ekonomiku v letech 2001-2002, kdy to byla v průmyslově vyspělých státech právě tato skupina obyvatelstva, která byla touto dekonjunkturou postižena nejvíce.

Relativně nízká míra nezaměstnanosti, která se v minulosti udržovala jak v Japonsku, tak v USA ${ }^{32}$, tj. ve dvou zemích, kde systém outsourcingu je důsledně uplatňován již téměř dvě desetiletí, byla zprvu považována za důkaz toho, že v důsledku posílení konkurenceschopnosti dosaženého zdejšími průmyslovými podniky díky uplatňování tohoto systému a tím daného rozšiřrení jejich odbytových možností zde nedocházelo k poklesu, nýbrž naopak $\mathrm{k}$ růstu počtu pracovních příležitostí. $\mathrm{V}$ následném grafu zachycený radikální pokles zaměstnanosti, zaznamenaný ve většině technologicky méně náročných oborů US průmyslu již koncem 90. let, jenž přetrvává i nadále, přestože zde došlo již v roce 2003 k robustnímu oživení hospodářské aktivity, však svědčí o tom, že pod vlivem výše popsaných globalistických konkurenčních praktik dochází i zde k postupné desindustrializaci. Témuž nasvědčuje výrazný nárůst ztrát pracovních příležitostí, $\mathrm{k}$ němuž dochází v současné době v Japonsku, hlavně v důsledku zániku tisíců malých a středně velkých průmyslových a řemeslných podniků, jimž se nepodařilo obstát v konkurenci s obdobnými podniky v sousedních zemích, kde mzdy (resp. pracovní náklady) jsou dosud řádově nižší.

32 V Japonsku se pohybovala v této době okolo $5 \%$, v USA okolo 4,5 \% práceschopného obyvatelstva. 
Tab. č. 1: Vývoj zaměstnanosti v hlavních průmyslových odvětvích USA (v tisíci osobách)
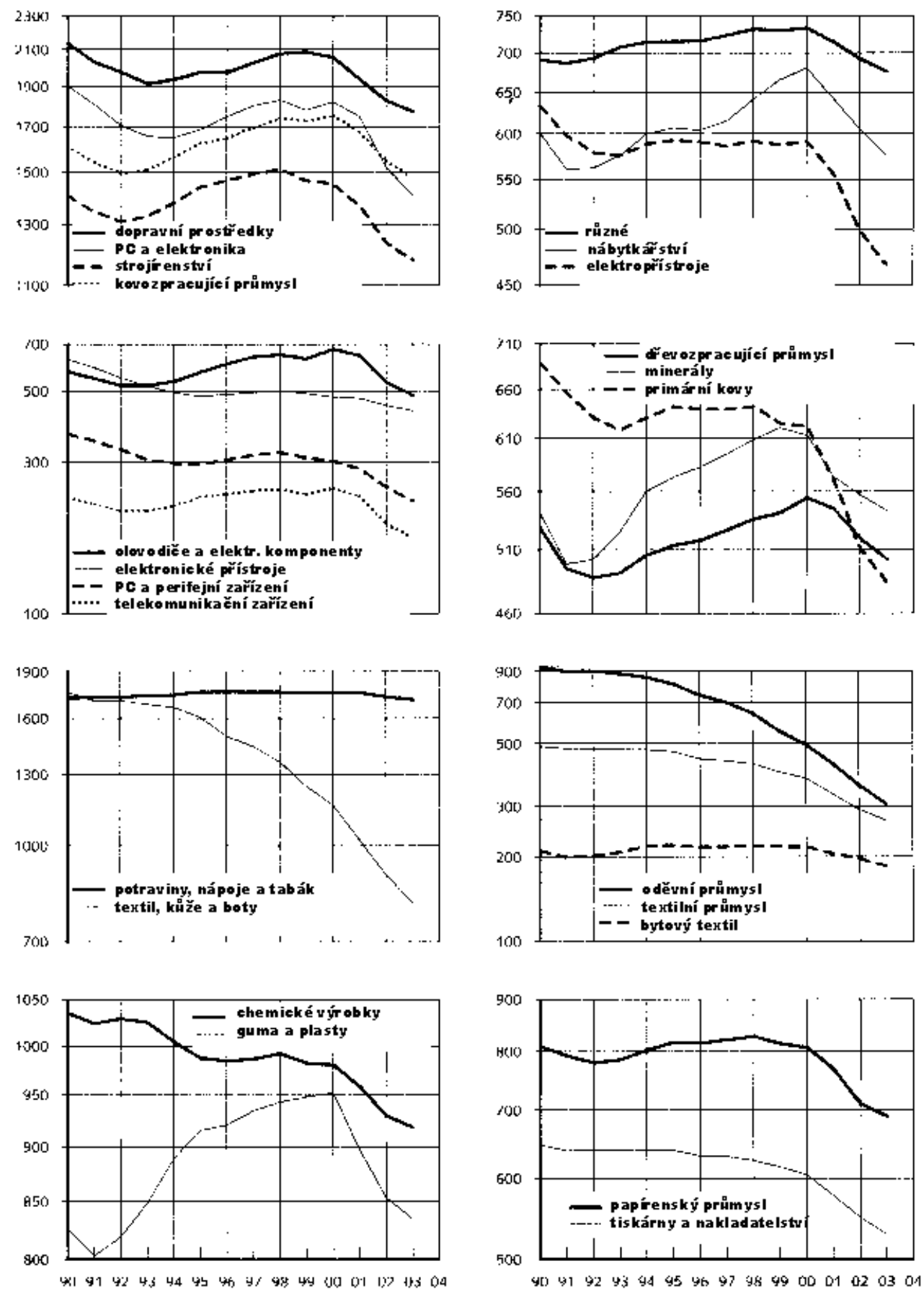

Pramen: „Conjoncture Economique et Financiére“ REXECO, Paris. X.2003. 
Rozvinutí těchto desindustrializačních procesů je však připisováno i výše popsanému rozmachu systému ,internacionální výroby“, nebợ ten vyústil v dislokaci nejen „pracovně náročných“", nýbrž i četných segmentů vysoce sofistikovaných, výzkumně náročných výrob do „mladých ekonomik“. Někteři ekonomové v tom spatřují hrozbu rentabilitě celých průmyslových oborů, z nichž některé mají pro prosperitu zralých tržních ekonomik přímo klíčový význam (elektronika, automobilový, strojírenský, hutní a petrochemický průmysl atp.). Obávají se totiž, že v důsledku zvýšení podílu „mladých ekonomik“ mezi dodavateli takovýchto výrobků a pod vlivem sílící konkurence jejich podnikatelů, jejichž „konkurenční práh “33 bývá podstatně nižší než ten, jenž vykazují podnikatelé se sídlem ve zralých tržních ekonomikách, klesnou ceny, za které jsou tyto výrobky či polotovary (celosvětově) obchodovány, zanedlouho na úroveň, která již nepokryje podstatně vyšší výrobní náklady jejich výrobců se sídlem ve zralých tržních ekonomikách. Prozatím to vyústilo pouze v radikální pokles zisků zdejších výrobců některých polotovarů, pocházejících z technologicky nenáročných výrob. ${ }^{34}$ Ozývají se však varovné hlasy poukazující na to, že nepodaří-li se zdejším podnikům (nejen výrobcům polotovarů, nýbrž i finálních výrobků) urychleně přizpůsobit nové situaci podnikatelské strategie a nebudou-li použitelnosti těchto strategií napomáhat hospodářsko-politická opatření uplatňovaná v zemi jejich sídla, mohlo by to vést $\mathrm{k}$ ohrožení jejich perspektiv. Zdůrazňují, že by to mohlo mít pro země sídla těchto podniků též závažné makroekonomické důsledky, počínaje oslabením jejich průmyslového potenciálu a zvýšením zdejší míry nezaměstnanosti, až po deceleraci jejich ekonomického růstu a oslabení jejich pozic ve světové ekonomice.

\section{Změny podnikatelských strategií podmiňující posílení kon- kurenceschopnosti členských států v EU}

Povědomí těchto rizik se stalo v Evropské unii již v předchozích čtyřech letech podnětem pro rozvinutí řady iniciativ cílených na posílení konkurenceschopnosti jejich členských států. Vedlo však i ve zdejší podnikové sféře k úpornému hledání nových koncepčních přístupů ke zvyšování konkurenceschopnosti, které by odpovídaly lépe - než ty, které jsou zde dosud uplatňovány - změněné situaci v mezinárodním konkurenčním prostředí, jakož i meritorním změnám v mezinárodní dělbě práce, navozeným globalizací světové ekonomiky. Nestačíme v této krátké stati popsat všechna opatření uplatňovaná či předvídaná za tímto účelem. Pokusíme se však objasnit alespoň stěžejní poznatky, z nichž vycházejí.

- Především vycházejí z poznatku, že globalizace světové ekonomiky je ireversibilním procesem, právě tak jako vznik nové „hospodářské mapy naši planety“, podněcovaný mimo jiné i uplatňováním výše popsaných globalistických metod konkurenčního zápolení. Nezbývá tudíž, než vzít na vědomí, že četné technologicky nenáročné typy výrob se stanou již zanedlouho doménou rozvojových zemí či „mladých ekonomik“, v konkurenci s jejichž podnikateli mají výrobci se sídlem ve zralých tržních ekonomikách jen velmi omezené šance uspět. Lépe řečeno: nemají možnost uspět v konkurenci s nimi s použitím tradičních konkurenčních metod vžitých v mezinárodním obchodě „homo-

33 „Konkurenční práh“ je dán jednak úrovní výrobních nákladů, se kterou musí daný podnikatel počítat při zabezpečování jim reálně prováděných aktivit, jednak mírou zisku dosažitelnou v jiném oboru či odvětví, kde by se mohl uplatnit, pakliže by v dané výrobě neuspěl. Konkurenční práh podnikatelů v nejméně vyspělých rozvojových zemích bývá mimořádně nízký nejen proto, že využívají zde vžitou subnormální hladinu mezd a pracovních nákladů, nýbrž i proto, že jediná alternativní možnost jejich uplatnění bývá zpravidla v oblasti zemědělství, kde míra zisku bývá extrémně nízká. Podrobněji viz: Sereghyová J.: „Konkurencia és koordináció a világpiacon“ Közgazdasági és jogi Könyvkiadó". Budapest, 1974.

34 Např. základních hutních výrobků, polovodičů, řady technologický nenáročných komponentů určených pro automobilový průmysl. 
genními produkty“, tj. díky snižování svých výrobních nákladů a cen pod hladinu cen přijatelnou pro tyto jejich konkurenty. Mají možnost udržet se v daném výrobním oboru jen tehdy, podaří-li se jim distancovat se od konkurenčních tlaků dodavatelů se sídlem v zemích kde pracovní náklady jsou řádově nižší než ty, s kterými musejí sami počítat.

- V minulosti se dařilo výrobcům se sídlem ve zralých tržních ekonomikách distancovat se od konkurenčních tlaků výrobců se sídlem v hospodářsky méně vyspělých zemích hlavně tím, že kvalita jejich výrobků byla lepší a že nesly renomované výrobní značky, popř. i tím, že se zaměřili na zabezpečování technologicky náročnější části daného sortimentu. To však ve změněném konkurenčním prostředí nepostačuje, nebở dnes se daří vyrábět v rozvojových zemích i v „mladých tržních ekonomikách“ již i technologicky náročnější výrobky či polotovary vykazující dokonalou kvalitu a jsou-li zde vyráběny afilacemi multinacionálních korporací, nesou zpravidla též renomované výrobní značky. Jediná možnost jak se dnes distancovat od konkurenčního tlaku zdejších výrobců tudíž spočívá v kontinuálním inovování vlastností těchto výrobků a v takovém rozšíření „služeb zákazníkům“, které výrobci v zemích vzdálených od uživatelů př́ísl. výrobků tisíce kilometrů, zpravidla nestačí na patř̌ičné úrovni poskytovat. Jde však zřejmě o způsob posilování jejich konkurenceschopnost, jehož účinnost nemá dlouhodobý horizont, nebot multinacionální korporace vyrábějící tyto výrobky v rozvojových zemích, patrně stačí zanedlouho vylepšit i svůj zákaznický servis.

- Daleko racionálnější reakcí výrobců se sídlem ve zralých tržních ekonomikách na vznik této situace, by byl jejich odchod z dané výroby. K takovémuto radikálnímu kroku se však dosud odhodlaly ve členských státech EU jen některé mohutné průmyslové korporace ${ }^{35}$ (mimo jiné i proto, že zánik jejich domácích provozů nemusí vést $\mathrm{k}$ jejich odchodu z daného mezinárodního trhu zboží, vyrábějí-li jejich tradiční výrobky nadále jejich afilace se sídlem v rozvojových zemích). Zdejší provozovatelé malých a středně velkých podniků, - z nichž většina dosud neinvestuje v zahraničí a kteří mívají dosud na domácí půdě pouze omezené možnosti alternativního uplatnění - se však všemožně pokouší oddálit svưj zánik. ${ }^{36}$ Mưže jim v tom napomoci leda to, že přenesou též část svých výrobních programů do zemí s nižší hladinou mezd. A k tomu jim skýtá nedávné rozšíření Evropské unie o osm nových členských států z řad transformačních zemí, velice příznivou príležitost.

Alternativní řešení této situace by spočívalo v přenesení aktivity těchto podniků do výzkumně a „znalostně“ náročných výrob, do výrob vyznačujících se vysokým inovačním rytmem, do výrob vyžadujících špičkovou kvalifikaci a adaptibilitu pracovních. sil, tj. do takových výrob, na které dosud doléhají konkurenční tlaky výrobců se sídlem v rozvojových zemích jen v ojedinělých případech. Významná část opatření, uplatňovaných Evropskou unií v rámci své kohezní a strukturální politiky je cílená na rozšíření alternativních možností uplatnění malých a stř̌edních podniků právě v takovýchto výrobách a oborech. Podrobněji se těmito politikami a $v$ jejich rámci realizovanými programy podpory malých a středně velkých podniků (i zvyšování kvalifikace jejich pracovníků) zabývají jiné studie, zpracované na půdě IČRE (z nichž některé byly publikovány již v letech 2001-2003). ${ }^{37} \mathrm{Na}$ tomto místě se tudíž můžeme omezit na konstatování, že tato opatření reprezentují vý-

35 Takovýto postup mohutných korporací stojí i za omezením zaměstnanosti v řadě průmyslových oborů v USA, znázorněném v grafu č. 1.

36 Přesto se právě tato skupina podniků podílí největší měrou na bankrotech, zaznamenaných v posledních letech $\mathrm{v}$ jednotlivých členských státech EU.

37 Viz nb.vse.cz/icre. 
znamný instrument, napomáhající „přežitíi právě této kategorie podniků, nejvíce postižených nebývalým zesílením konkurenčních tlaků, jimž je provázena globalizace světové ekonomiky.

- Tak jak se podaří v jednotlivých členských státech EU vytvořit podmínky pro přesun malých a středně velkých podniků do takovýchto technologicky náročných výrob (i nevýrobních aktivit), budou i ony konfrontovány převážně jen s konkurenty se sídlem ve zralých tržních ekonomikách. To však platí o zdejších mohutných (multinacionálních) korporacích již dnes, nebot’mnohé z nich se distancovaly již v 90 . letech od konkurenčních tlaků výrobců technologicky méně náročných variant jimi produkovaných druhů zboží budtím, že zcela opustily technologicky nenáročné výrobní obory, anebo tím, že ve svých provozech se sídlem ve zralých tržních ekonomikách provádí již jen technologicky náročné operace, (zatímco technologicky méně náročné subdodávky čerpají ze zemí s nižšími pracovními náklady). Existuje zde sice řada korporací, které tak nepostupovaly. Většina z nich se však dnes nachází ve vážných nesnázích.

- Současně s tímto přesunem ve struktuře jejich zahraničních konkurentů, (mezi kterými jsou nadále zastoupené převážně jen podniky se sídlem v hospodářsky vyspělých zemích) se však stalo důsledné uplatňování celého spektra globalistických konkurenčních praktik uplatňovaných jejich hlavními konkurenty již řadu let, pro všechny mohutné (i pro mnohé středně velké) evropské průmyslové podniky kategorickým imperativem. V opačném případě by se totiž výrazně oslabily jejich šance na úspěch v konkurenčním zápolení s konkurenty, nebot kalkulační zvýhodnění, k nimž dopomáhají některé z těchto praktik, bývají tak rozsáhlá, ${ }^{38}$ že důsledky jejich neuplatnění nelze vyvážit žádnými jinými metodami zvyšování konkurenceschopnosti. ${ }^{39}$ Lze tudíž očekávat, že mohutné západoevropské korporace budou nadále - v daleko větší míře než dosud přenášet části svých výrob (výrobních programů) do zahraničí. V prvé fázi to bude v zemi jejich sídla patrně podvazovat růst zaměstnanosti. V druhé fázi - tak jak tato strategie bude napomáhat posilování jejich konkurenceschopnosti, bude však docházet k rozšiřování nejen jejich domácích, nýbrž i jejich zahraničních odbytových možností, jež zde dopomůže k plnějšímu vytížení výrobních kapacit i k nárůstu počtu pracovních příležitostí. Pouze tak lze předejít dalšímu poklesu podílu těchto států na světovém ex-

38 Rozdíly v př́istupu jejich podnikové sféry k uplatňování takovýchto globalistických principů mezinárodní dislokace jejich průmyslových výrob bývají též považovány za jeden z důležitých důvodů pro dosud přetrvávající rozdíly v konkurenceschopnosti tř́ členů „triády“.

39 Oprávněnost těchto presumpcí ostatně potvrzuje i zjištění, že mezera mezi konkurenceschopností EU a druhými dvěma regiony „triády“, se v poslední době nejen nezmenšila, nýbrž v některých ohledech se dokonce zvětšila. (např. v tempu růstu produktivity práce, v rozsahu podnikatelských zisků, v samotných tempech ekonomického růstu. (Viz „Conjoncture Economique et Financiére“ REXECO, Paris X/2003. Též UNCTAD, Handbook of statistics, U.N. 2003).

Tempa ekonomického růstu v jednotlivých regionech „triády (meziroční \% změny HDP)

Pramen: World Economic Outlook, IMF, Wash D.C. IX. 2003. a (p) = prognóza AIECE.

Zaostávání temp ekonomického růstu EU zaznamenané v posledních dvou letech bylo zprvu přičítáno hlavně posilování směnného kurzu EURA, nebot ten výrazně oslabil konkurenceschopnost zdejší podnikové sféry na zahraničních trzích a současně posílil konkurenceschopnost podnikatelů se sídlem ve „třetích zemích“ na Jednotném vnitřním trhu EU. V současné době je však již zřejmé, že ke zvětšení této mezery přispěl významnou měrou též zdrženlivý postoj, který zdejší korporace dosud zaujímají k uplatňování některých z výše popsaných globalistických konkurenčních praktik. Přenášejí do zahraničí převážně jen technologicky nejméně náročné segmenty svých výrobních programủ, které při relativně vysokých pracovních nákladech ustálivších se v zemích jejich sídla, zde nelze již provozovat (aniž by jim tím vznikly rozsáhlé ztráty). Ostatní části svých výrob provozujív možné míre ,in-house“ (resp. na domácí půdě), čímž přicházejí o valnou část přínosů dosažitelnou důslednou internacionalizací jejich výroby. 
portu (výrobků zpracovatelského průmyslu), jenž by měl na vývoj situace na jejich trhu práce nepoměrně závažnější dopady.

Tab. č. 2: Proměny podílů členů „triády“ na světovém exportu výrobků zpracovatelského průmyslu (v \%, SITC 5-8 bez SITC 68$)$

\begin{tabular}{|c|c|c|c|c|}
\hline léta & svět & Evropská unie & USA & Japonsko \\
\hline 1990 & 100,0 & 44,0 & 15,0 & 3,8 \\
\hline 1995 & 100,0 & 37,9 & 15,9 & 4,4 \\
\hline 2000 & 100,0 & 36,0 & 19,5 & 4,1 \\
\hline
\end{tabular}

Pramen: UNCTAD, Handbook of Statistics, 2003. OSN, Geneva.

- Jakmile přejdou mohutné průmyslové korporace se sídlem v hospodářsky nejvyspělejších členských státech EU na důslednější uplatňování globalistických konkurenčních praktik, získá pro posílení jejich konkurenceschopnosti na významu též existence vhodného zázemí pro mezinárodní dislokaci částí jejich výrob. ${ }^{40}$ Záleží nejen na rozsahu tohoto zázemí (resp. „operačního pole“), nýbrž i na př́ínivých legislativních i obchodně-politických podmínkách $\mathrm{v}$ nichž budou moci navazovat vztahy s tamějšími podniky. Záleží ovšem i na způsobilosti těchto podniků dokonale zvládnout jim delimitované aktivity a zabezpečovat je za podmínek, které těmto korporacím poskytnou kalkulační zvýhodnění srovnatelné s tím, které - díky internacionalizaci své výroby - zabezpečují jejich konkurenti. Se zřetelem k těmto kauzálním vazbám nemůže být pochyb o tom, že rozšiřrení Evropské unie na východ může sehrát při posilování mezinárodní konkurenceschopnosti těchto korporací důležitou roli. Populace Evropské unie rozšířením totiž dosáhla stejnou četnost jako populace NAFTA (tj. cca 105 mil. osob). Rozšíríla se o 8 transformačních zemí, v nichž se budou mzdové hladiny pohybovat ještě řadu let na úrovni, vžité v „mladých ekonomikách“ $v$ jiných regionech světové ekonomiky, přičemž kvalifikace pracovních sil a jejich kvalitativní disciplína bývají mnohdy lepší. Skutečnost, že vzdálenost zdejších podniků od jejich západoevropských odběratelů, př́kazců či „mateřských společností" se bude zpravidla pohybovat pouze v rozsahu několika set kilometrů (někdy bude ještě menší), zatímco zámořští konkurenti těchto západoevropských korporací dopravují své subdodávky nezřídka na vzdálenost tisíců kilometrů jim poskytne další kalkulační zvýhodnění. Významné zvýhodnění jim zabezpečuje i skutečnost, že jejich vztahy s dodavateli či subdodavateli anebo kooperačními partnery v nových členských státech EU se budou odvijet v konsolidovaných podmínkách a v legislativním rámci daném Acquí communautaire, jenž vytváří záruky regulérnosti a omezené riskantnosti těchto mezipodnikových vztahủ. ${ }^{41}$

40 Na důkaz toho lze uvést dramatické posílení konkurenceschopnosti severoamerických průmyslových korporací, zaznamenané po vytvoření NAFTY (tj. Severoamerické zóny volného obchodu). Obdobné účinky mělo užší (kapitálové, organizační i funkční) propojení mohutných japonských korporací s podnikovou sférou blízkých nově industrializovaných zemí i s podniky operujícími ve „zvláštních ekonomických zónách“ vytvořených v přímořských oblastech Čínské lidové republiky.

41 Jde nyní jen o to nepromarnit tuto ojedinělou šanci pro vytvoření mimořádně příznivého „operačního zázemí“ či subdodavatelské základny pro mohutné západoevropské průmyslové podniky tím, že jejich potenciálním subdodavatelům či kooperačním partnerům se sídlem v „nových členských státech EU“ by byla odepřena možnosti využivat i nadále některé jejich tradiční komparativní výhody. Touto možností je totiž podmíněno nejen zachování láce jejich dodávek, nýbrž mnohdy i prolongace jejich existence. Jde o problematiku, která se vymyká z tématiky, jíž se věnován tato stat. Zabývají se jí však jiné studie zpracované na půdě IČRE. Viz např. J. Sereghyová: „Faktory ovlivňující konkurenční schopnost zpracovatelského průmyslu České republiky před a v prvých letech po jejím vstupu do EU“. Úřad vlády ČR, 2000. 
- Současná podoba ekonomické mapy naší planety - tak jak se vyvinula pod vlivem integračních procesů a v důsledku vzniku „zón volného obchodu“ i jiných forem propojení ekonomik jednotlivých států - však není trvalým jevem, nýbrž se bude měnit a to jak ve střednědobém, tak zejména $\mathrm{v}$ dlouhodobém horizontu. Současně $\mathrm{s}$ tím se bude měnit též rozsah a charakteristiky „operačního zázemí“, ${ }^{42}$ jimž budou disponovat jednotlivé multinacionální korporace, což významnou měrou ovlivní jejich konkurenceschopnost. $\mathrm{S}$ přihlédnutím $\mathrm{k}$ této skutečnosti získává $\mathrm{v}$ současné době připravované založení nové zóny volného obchodu, zahrnující téměř celý region jihovýchodní Asie (jehož populace čítá více než půl miliardy osob) pro perspektivy multinacionálních korporací operujících v tomto regionu, přímo klíčový význam. Obdobně i předvídané založení tzv. „Celoamerické oblasti volného obchodu" (All-american Free-trade Area), - tj. zóny volného obchodu typu „NAFTA“, která bude patrně zahrnovat všechny latinsko-americké státy, jejichž populace převyšuje též půl miliardy osob, - zabezpečí severoamerických multinacionálním korporacím operační zázemí nebývalých rozměrů. Netřeba zdůrazňovat, že na tento růst „operačního pole“ jejich zámořských konkurentů, rýsující se již ve střednědobém horizontu, by se měly mohutné evropské průmyslové korporace zavčas připravovat především tím, že budou usilovat o obdobné rozšíření svého „výrobního zázemí".

- Uspějí-li tyto korporace, mohlo by to přispět nejen $\mathrm{k}$ uhájení či dokonce $\mathrm{k}$ posílení jejich pozic v mezinárodním obchodě, nýbrž i ke zlepšení situace na trhu práce $v$ jednotlivých členských státech EU. Ve zdejší akademické obci se tudíž setkáváme stále častěji s názorem, že by bylo na místě aby takovémuto rozšíření jejich „operačního zázemí“ napomáhala též obchodně politická opatření uplatňovaná jednotlivých členskými státy EU, jakož i celounijní reglementace jejich mezinárodních hospodářských vztahů. Měla by napomáhat vytvoření takových legislativních podmínek pro rozvoj subdodavatelských a kooperačních vztahů těchto korporací s partnery za hranicí Evropské unie, které by jim umožnily ve „třetích zemích“ vybudovat obdobně výhodnou a rozsáhlou subdodavatelskou základnu, jakou budou již ku konci běžného desetiletí disponovat jejich zámořští konkurenti. Bývá poukazováno na to, že prohloubení obchodně - politických vazeb s těmi jihoevropskými a východoevropskými transformačními zeměmi (které dosud nefigurují mezi kandidáty na členství v EU) by mohlo přitom sehrát důležitou roli nejen proto, že souhrn občanů těchto zemí odpovídá v hrubých rysech populaci zemí spadajících do výše uvedených dvou mohutných nových zón volného obchodu formujících se na Dálném východě a v Americe, nýbrž i proto, že jak zdejší mzdové hladiny, tak i kvalifikace a kvalifikovatelnost zdejších pracovních sil vytváří pro takovéto využití průmyslového potenciálu těchto zemí reálné předpoklady.

Takovýmto směrováním obchodně-politických iniciativ členských států EU se budou zabývat další studie, zpracované na půdě IČRE. Na tomto místě se tudíž omezíme jen na konstatování, že těmto iniciativám připadá mimořádně důležitá úloha nejen při obhajování pozic mohutných evropských korporacíve změněných podmínkách s nimiž se budou setkávat na zahraničních trzích již na přelomu tohoto a př̌štího desetiletí, nýbrž i při zabezpečení „šance na přežití tisíců malých a středně-velkých podniků rozmístěných v různých členských státech EU, které jsou či budou do podnikatelských sítí těchto korporací zapojeny a budou tudíž sdílet jejich osud.

42 Současná míra liberalizace mezinárodního obchodu, jakož i „otevřenost“ kapitálových trhů většiny států světa mezinárodnímu pohybu kapitálu umožňuje sice multinacionálním korporacím operovat v kterékoli tržní ekonomice. Existence výše zmíněného „operačního zázemí“ které jim skýtá možnost internacionalizovat svou výroby za zvýhodněných (obchodně-politických a legislativních) podmínek, je však pro zachování či posílení jejich konkurenceschopnosti přesto velmi důležitá. 


\section{Nosné elementy konkurenceschopnosti jednotlivých členských států EU v mezinárodním srovnání}

Jak mezi akademiky, tak i mezi národohospodáři členských států EU je značně rozšířené přesvědčení, že posílení cenové konkurenceschopnosti těchto států lze přenechat z valné části iniciativě jejich podnikové sféry, že bude závislé především na tom, s jakou účinností se podaří zabezpečit ve zdejším průmyslu zvýšení produktivity práce a s jakou rychlostí si zdejší průmyslové podniky osvojí uplatňování výše zmíněných globalistických podnikatelských strategií. Uvědomují si však, že pro tyto státy - jako ostatně pro všechny hospodářsky vysoce vyspělé tržní ekonomiky - má nemenší (a v řadě případů dokonce větší) význam posílení jejich technologické konkurenceschopnosti, jež jejich podniková sféra mnohdy nestačí zabezpečit pouze „vlastními silami“. Vyžaduje totiž nezrrídka provedení meritorních změn v zaměření činnosti celých skupin podniků (viz žádoucí reorientace aktivit malých a stř̌edních podniků zmíněná v předchozím textu), či v oborové struktuře některých odvětví, anebo v přístupech jednotlivých členských států EU k posilování jejich vědecko-technického potenciálu. To je též důvodem, proč podmínkám zabezpečení takovýchto posunů a strukturálních změn, podmiňujících posílení technologické konkurenceschopnosti těchto států, je zdejší akademickou obcí již řadu let věnována zvýšená pozornost.

- Při zvažování - z těchto důvodů žádoucích - změn sektorové struktury jejich ekonomik se vycházelo zprvu z premisy, že to byl hlavně rychlý růst terciárního sektoru v ekonomice USA, co přispělo v 90. letech největší měrou k posílení jejich konkurenceschopnosti $^{43}$. Z toho se vyvozovalo, že v Evropské unii by mohlo posílení relativní váhy „tržních služeb“44 mezi zdroji hrubého domácího produktu členských států mít obdobné pozitivní účinky. Hloubkové analýzy prováděné na některých z nejrenomovanějších západoevropských výzkumných pracovištích ${ }^{45}$ však zanedlouho prokázaly, že pozitivní vliv na konkurenceschopnost zemí nemívá rozvoj všech typů služeb, nýbrž převážně jen tzv. „služeb podnikatelských“ (business-related-services), přičemž i mezi těmi jsou některé, které mívají řadu závažných zpětných vazeb. ${ }^{46}$ Ukázalo se kromě toho, že to byl dramatický rozmach celého sektoru informačních technologií (a v rámci toho i jim poskytovaných služeb), co přispělo v 90. letech největší měrou k posílení konkurenceschopnosti USA a to nejen proto, že konkurenceschopnost tohoto sektoru výrazně převyšovala $\mathrm{v}$ předchozí době dosažený celostátní průměr, nýbrž i proto, že masové uplatnění IT produktů i služeb ve všech oblastech hospodářského života USA, zde vyústilo v neobvykle silný nárůst produktivity práce.

43 Ta se zračila nejen ve vysokých tempech ekonomického růstu USA zaznamenaných zde od r. 1992 až do konce 90. let, nýbrž i v jejich silné exportní výkonnosti, která zde přetrvávala v té době nezávisle na velice silném směnném kurzu USD.

44 Tj. služeb poskytovaných jak podnikům tak i obyvatelstvu za úhradu, (na rozdíl od tzv. „sociálních služeb“ financovaných ze státního rozpočtu anebo z jiných veřejných zdrojů).

45 Na půdě analytické divize Spojených národů i na půdě CPB-Netherlands.

46 Jde zde hlavně o tzv. leasingové, zprostředkovatelské i jiné obchodní služby, jakož i o údržbářské a bezpečnostní služby, i o široké spektrum „osobních služeb“ poskytovaných obyvatelstvu za úhradu, které se vyznačují tím, že skýtají jen omezené možnosti pro zvyšování produktivity práce. To může vést k rozvoji tzv. „Baumolovi choroby“ zračící se ve skutečnosti, že s růstem podílu těchto služeb na tvorbě HDP př́sl. země se snižují tempa jejího ekonomického růstu. Prokázalo se kromě toho, že sektor služeb v prvých fázích posilování svého postavení v ekonomice dané země, stačí jen zřídkakdy vstřebávat pracovní síly uvolněné z výrobního procesu v důsledky její desindustrializace, že tedy vede nezř́́dka ke zhoršení situace na jejím trhu práce. Viz Kox, H.: „Business services and the Baumol disease“ CPB Report 2002/3, Den Hague, 2002. 
- Zvýšený důraz kladený v současné době ve všech členských státech EU jednak na rozvoj sektoru informačních technologií, jednak i na hojnější využití jeho produktů a služeb ve zdejší podnikové sféře vychází z premisy, že to povede nejen ke stejně robustnímu posílení její (technologické) konkurenceschopnosti, nýbrž i ke stejně výraznému zvýšení podnikatelských ziskủ jako v 90 . letech v USA ${ }^{47}$. Většina evropských akademiků i praktiků se dnes již shoduje v názoru, že prvá z uvedených premis je veskrze reálná. Reálnost druhé z nich je však některými zdejšími teoretiky zpochybňována. Poukazují na to, že vysoké zisky zabezpečované americkými multinacionálními korporacemi operujícími v sektoru informačních technologií byly dány nejen tím, že šlo o vysoce poptávané produkty a služby, nýbrž i tím, že vyvinuly mnohé z těchto technologií v předstihu před ostatními podnikateli zastoupenými v tomto oboru, což jim dopomohlo na globálním IT trhu k monopolním pozicím (a ke zvýšeným ziskům odpovídajícím této skutečnosti). $Z$ toho vyplývá, že zaměří-li se evropské korporace operující v IT sektoru i v některých dalších oborech spadajících do kategorie vysokých technologii $^{48}$ převážně jen na urychlené „,dohnání technologického náskoku, jenž získaly v příslušném oboru některé zahraniční korporace (nejen severoamerické, nýbrž i japonské), nebude nárůst jejich zisků zdaleka tak dramatický jako ten, jenž byl v 90.letech zaznamenán v ostatních dvou regionech „triády“. K tomu může dojít jen tehdy, podaří-li se evropským korporacím též vyvijjet opakovaně inovace vyšších řádů $\mathrm{v}$ předstihu před svými konkurenty, zařadí-li se v některých oborech spadajících do kategorie „vysokých technologii“ trvale mezi nositele fundamentálních inovací. A to nezávisí pouze na inovační zdatnosti kterou stačí vyvinout tyto korporace, nýbrž i na souhrnném vědecko-technickém potenciálu země jejich sídla.

Povědomí této skutečnosti se již promítlo do rozhodnutí členských států EU vynakládat na výzkum a vývoj prostř̌edky, odpovídající zhruba $3 \%$ jejich hrubého domácího produktu. Je předvídáno, že $\mathrm{k}$ takovémuto navýšení prostředků určených na posílení vědecko-technického potenciálu těchto států přispěje nejen podniková sféra (zejména mohutné korporace), nýbrž i jejich státní aparát, jenž bude - podstatně silněji než dosud financovat zejména základní výzkum. Je též předvídáno, že v těchto státech dojde v historicky krátké době ${ }^{49}$, též k hojnějšímu financování jejich vysokého školství, jakož i k uplatnění řady dalších opatření, která vyústí v radikální posílení (zejména technologické) kvalifikace jejich občanů.

- Uplatnění těchto opatření je však motivováno nejen snahou uspíšit zde rozvoj oborů spadajících to kategorie vysokých technologií, jež se zračí v jejich „technologické konkurenceschopnosti“. Je motivováno též úsilím, vytvořit ve zdejší podnikové sféře předpoklady pro hojnější využívání z těchto oborů pocházejících produktů a služeb i jiných technologických vymožeností, které by zde vedly k radikálnímu zvýšení produktivity práce i kvality samotných výrobků. Má za cíl přispět též ke zvýšení tzv. „kapacitní konkurenceschopnosti“ těchto států (která odráží technologicky dané posuny v produkti-

47 Podnikatelské zisky převyšovaly v USA vždy úroveň zisků dosahovanou ve většině evropských tržních ekonomik. V současné době však rozdíly mezi hladinou zisků dosahovanou podniky v těchto dvou regionech jsou násobné, což ostatně vede k odplývání investičního kapitálu z EU do USA. To sice ustalo v letech 2001 a 2002, tj. v době, kdy recese v ekonomice USA dosáhla své „dno“, v současné době (2004) však nanovo zesílilo.

48 Např. v biotechnolgii, ve farmaceutice, v mikroelektronice.

49 Po dovršení reformy státních financí probíhají v řadě těchto států, nebở v průběhu zavedení této reformy, která vyžaduje krácení většiny rozpočtových výdajů - se jeví podstatně navýšení prostř̌edků určených na vzdělání jen málo reálným. 
vitě práce dosažené v měřítku celé jejich podnikové sféry. ${ }^{50}$ ) Jak je patrné z následných dvou přehledů, posílily v 90 . letech svou technologickou konkurenceschopnost (danou výskytem vysoce sofistikovaných oborů) převážně jen zralé tržní ekonomiky a několik málo nově industrializovaných zemí. Transformační země (pouze s výjimkou Slovinska) však mezi nimi chyběly, přičemž i relativně slabá technologická konkurenceschopnost kterou tyto státy dosáhly již dříve, ve většině $\mathrm{z}$ nich $\mathrm{v}$ té době dále zaostávala. ${ }^{51}$ Mezi zeměmi, které v tomto časovém rozpětí (let 1993-2001) zaznamenaly podstatný nárůst tzv. „kapacitní konkurenceschopnosti“ (dané využitím progresivních technologií jejich podnikovou sférou), však figuruje již i řada transformačních zemí a to ve skupině, která „doháni““ kapacitní konkurenceschopnost zralých tržních ekonomik.

Tab. č. 3: Vývoj technologické konkurenceschopnosti celostátní průměry za léta 1993-2001

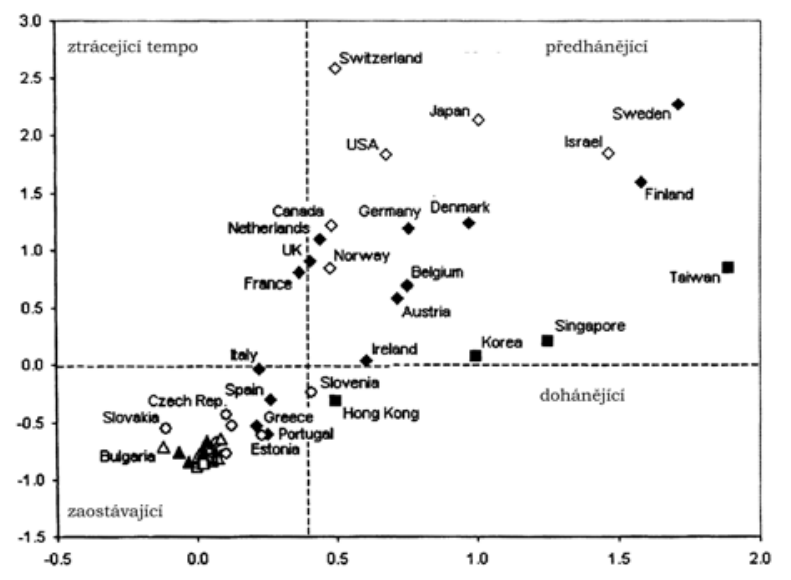

Vývojkapacitní

konkurenceschopnosticelostátní průměry za léta 1993-2001

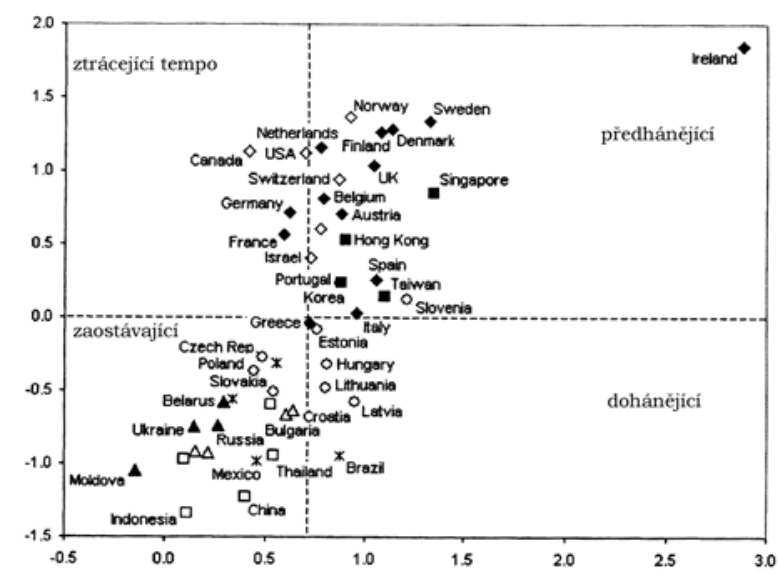

Pramen: J. Fagerberg a kol.. Seminář ECE/OSN, II. 2004.

50 viz Fagerberg, J., Knell, M., Srholec, M.: „The competitiveness of Nations: Economic Growth in the ECE Region". Spring seminar ECE/UN, February 2004.

51 To bylo dáno hlavně tím, že „domáci““ vysoce sofistikované výroby v těch letech pod tlakem zahraniční konkurence zanikaly, přičemž přiliv přímých zahraničních investic zde vyústil převážně jen v zakládání provozů zabezpečujících zušlechtovací styk či jiné technologicky nenáročné aktivity. 
Příčiny zde vyznačených rozdílů v kapacitní konkurenceschopnosti jednotlivých států se dosud nepodařilo objasnit. Existuje však řada hypotéz týkajících se kauzálních vazeb stojících za těmito rozdíly. Tak např. slabé př́růstky kapacitní konkurenceschopnosti zaznamenané řadou průmyslově vyspělých států (nejen evropských, nýbrž i zámořských) bývají připisovány jednak tomu, že hlavní posun směrem k modernizaci jejich průmyslové výroby i k uplatňování progresivních technologií zde proběhl již v předchozích letech, jednak i desindustrializačním procesům, které se zde prosazují v posledních letech se zvýšenou razancí (což ostatně potvrzuje tezi, že možnosti gradace produktivity práce v terciárním sektoru jsou velice skromné). Zaostávání růstu jak kapacitní, tak i technologické konkurenceschopnosti některých transformačních zemí bývá připisováno alternativně budjejich omezené způsobilosti „vstřebávat“ progresivní technologie, anebo skutečnosti, že zahraniční investoři zde zakládají převážně jen technologicky minimálně náročné výroby, (přičemž investiční aktivita domácích investorů je zde dosud značně omezená).

Nezávisle na tom, že jak kapacitní, tak zejména technologická konkurenceschopnost transformačních zemí je dosud slabá, rostla jejich celková konkurenceschopnost - a to hlavně kandidátů na vstup do EU - v uvedených letech relativně vysokými tempy. To svědčí o tom, že byla „nesena“ hlavně jejich cenovou konkurenceschopností, opírající se o využívání subnormální úrovně zdejších pracovních nákladů, zachycené i na následném pravém grafu.

Tab. č. 4: Proměny celkové konkurenceschopnosti vybraných států v letech 1993-2001 (HDP per capita, běžné USD v PPP) v \% (svět v r. $1997=100)$

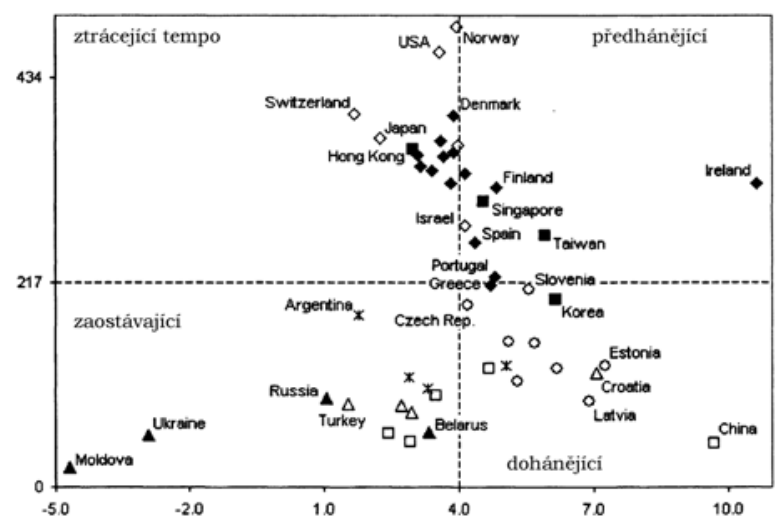

Jednotkové mzdové náklady ve zpracovatelském průmyslu států (v USD - průměr za 1993-2001)

Pramen: J. Fagerberg a kol. Seminář ECE/OSN, II. 2004.

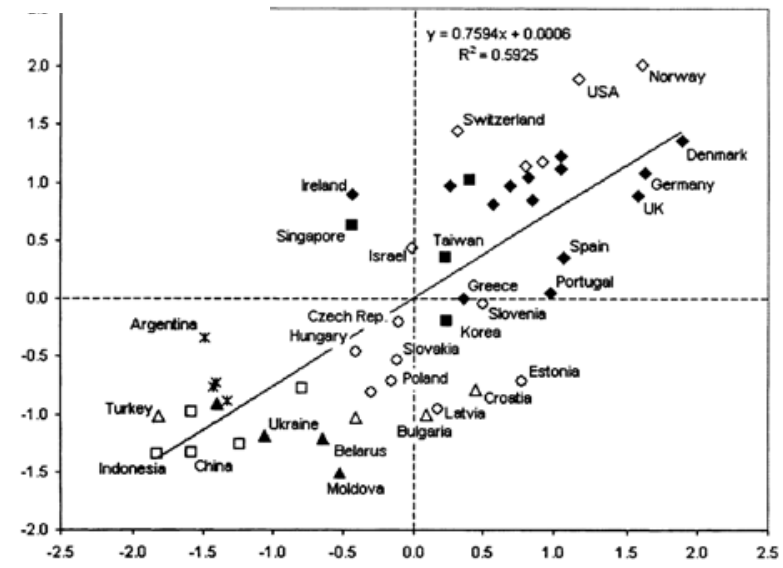


Z výše uvedeného levého grafu lze vyrozumět, že cenovou konkurenceschopnost sdílí transformační země s řadou „mladých ekonomik“, jejichž konkurenceschopnost a exportní výkonnost náležela v průběhu předchozího desetiletí $\mathrm{k}$ nejdynamičtěji narůstajícím v celosvětovém měřítku. To však nic nemění na závažnosti zjišsění, že tyto země jsou dosud odkázány na to, aby růst svých exportních výnosů zabezpečovaly hlavně navyšováním „hmoty“ svého exportu, že se jim dosud nepodařilo zařadit se mezi státy, jimž se to daří hlavně díky své orientaci na vývoz vysoce sofistikovaných druhů zboží a služeb, jejichž ceny narůstají hlavně pod vlivem zvyšování kvalitativní a inovační úrovně.

\section{Proměny v charakteru konkurenceschopnosti členských stá- tů EU navozené přechodem na znalostně fundovaný typ eko- nomického růstu}

Se zřetelem k uvedenému zjištění reprezentuje předvídaný přechod Evropské unie na uplatňování tzv. „znalostně-fundovaného“ (knowledge-based) typu ekonomického růstu, pro její nové členské státy z řad transformačních zemí, významnou šanci. Umožní jim totiž podílet se na přínosech širokého okruhu systémových opatření, která budou uplatňovaná za účelem zlepšení kvalifikace a technologické zdatnosti obyvatelstva jednotlivých členských států, či na podporu rozvoje jejich vědecko-technické a informační infrastruktury a jejího vzájemného propojení. To může těmto novým členským státům EU dopomoci nejen ke zvýšení „přidané hodnoty“ dosahované ve stávajících provozech, nýbrž i ke zvýšení podílu sofistikovaných výrob a služeb na tvorbě domácího produktu.

$\mathrm{V}$ míre, $\mathrm{v}$ jaké se podaří jejich podnikové sféře takovýto přesun $\mathrm{v}$ zaměření činnosti docílit, ocitne se mimo dosah konkurenčních tlaků podnikatelů se sídlem v hospodársky podstatně méně vyspělých zemích, což - samo o sobě - již skýtá předpoklady pro zvýšení efektivnosti jejich exportu. Ta by v tomto případě však narůstala též proto, že se zvýší podíl zboží a služeb s „,ysokou přidanou hodnotou“ na jejich exportním substrátu. Rýsuje se tak reálná možnost, že tyto země by se mohly postupem doby vymanit ze začarovaného kruhu v němž se většina z nich dosud pohybuje, kdy otevírání jejich ekonomik světu bývá nezř́íka provázeno robustnějším růstem dovozní náročnosti jejich podnikové sféry, než růstem její exportní výkonnosti; kdy tím navozený opakovaný výskyt rozsáhlých deficitů jejich obchodních bilancí vede k progresivnímu nárůstu jejich zahraničního zadlužení.

Nelze ovšem předpokládat, že zdejší podniky se stanou naráz nositeli inovací vyšších řádů. Jejich přechod na export výrobků a služeb s vyšší přidanou hodnotou se projeví v prvé fázi patrně převážně jen tím, že jejich podniky se stanou výrobci výzkumně a technologicky poněkud náročnějších výrobkủ či polotovarů, že některé z nich se zaměří na poskytování technologicky náročnějších „,podnikatelských služeb“. První příznaky takovéhoto přerodu lze prozatím pozorovat pouze v Mad'arskua Estonsku (jejichž podniky již figuruji mezi významnými vývozci počítačové techniky a softwaru, kde některé zde vyvinuté programátorské inovace již našly uplatnění též v zahraničí). Úspěchy dalších kroků „nových“ členských států EU podniknutých v tomto směru, budou zřejmě závislé především na tom, zda a jak se podaří jejich podnikům začlenit se do celoevropských podnikatelských sítí, jejichž konfigurace dozná v důsledku přechodu členských států EU na „znalostně fundovaný typ ekonomického růstu“ téě nemalé změny.

Výsledky výzkumu předložené na výše zmíněném Jarním semináři Hospodářské komise pro Evropu Spojených národů svědčí o tom, že mezi státy EU se vyskytují některé, kde lze již pozorovat pozitivní zvrat ve vývoji ukazatelů konkurenceschopnosti i dalších 
makroekonomických ukazatelů výkonnosti jejich ekonomik. Je pozoruhodné, že tento zvrat lze pozorovat prozatím pouze ve třech menších skandinávských zemích - v Dánsku, Švédsku a Finsku - zatímco ve třech kontinentálních státech EU vykazujících relativně největší ekonomický rozměr ${ }^{52}$, ve Francii, Itálii a ve Spolkové republice Německo se takovéto příznivé posuny ještě nerýsují. Diskuse probíhající na tomto semináři, i samotné výzkumné studie dokladující tyto rozdíly ${ }^{53}$ v konkurenceschopnosti i celkové ekonomické výkonnosti uvedených dvou skupin členských států EU, je připisují hlavně rozdílům v hospodářsko-politických opatřeních uplatňovaných v každé z nich, zejména pak těm, které se projevily v diametrálních rozdílech v rozsahu prostředků vynakládaných zde na tzv. „investice do budoucnosti“, tj. na výzkum a vývoj, na vzdělání a na rozvoj a užití informačních technologií. Tyto rozdíly jsou výstižně znázorněny v následném grafu.

Tab. č. 5: „Investice do budoucnosti““ podnikané v průběhu 90. let ve třech skandinávských zemích a ve třech ,velkých kontinentálních“ členských státech EU

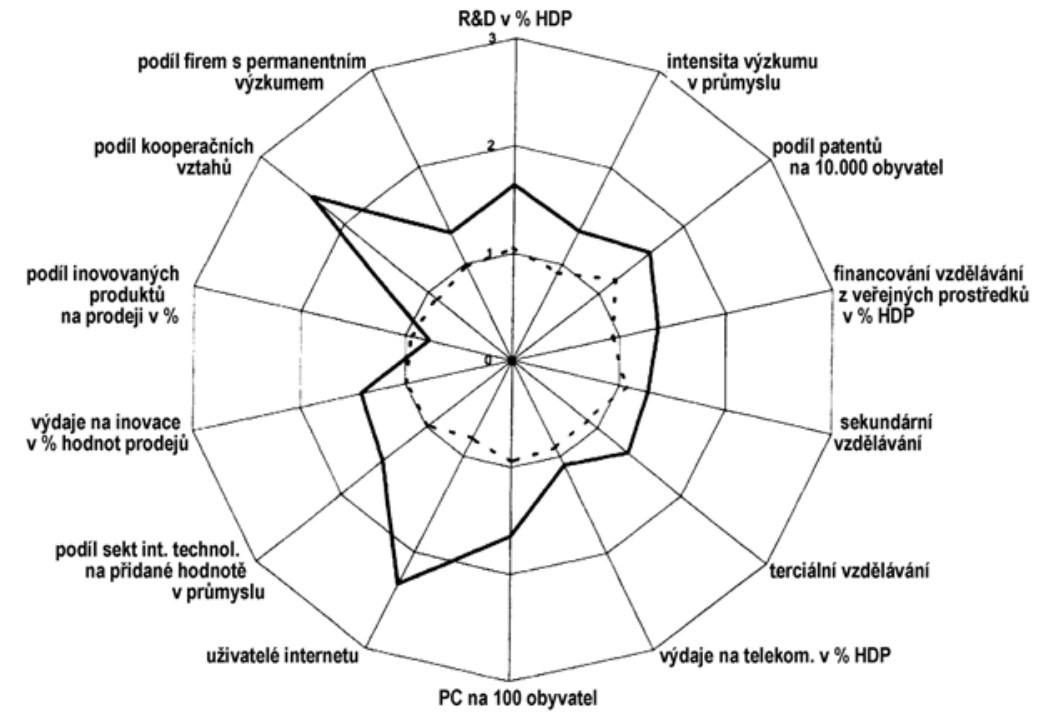

Pramen: K. Aiginger, WIFO, - Seminář ECE/UN. II. 2004.

Výsledky našich vlastních analýz svědčí o tom, že ke vzniku těchto rozdílů přispěly též pokusy státního aparátu uvedených kontinentálních členských států EU ochraňovat jejich podnikovou sféru před dopady dramatických změn probíhajících ve světové ekonomice v důsledku její globalizace. To vedlo totiž k ochabnutí konkurenceschopnosti řady zdejších podniků, jakož i k přetrvávání vysoké míry nezaměstnanosti promítnuvší se vzápětí i do zvýšeného napětí v jejich veřejných financích. Oprávněnosti naší hypotézy potvrzuje ostatně i následný graf, v němž jsou porovnávány nejen konkurenční, nýbrž i ostatní makroekonomické ukazatelé těchto dvou skupin států.

52 Nejde zde o rozměr v kilometrech ani o ten, který se zračí v počtu obyvatelstva dané země, nýbrž o charakteristiku její ekonomické výkonnosti tj. o poměr mezi jejím HDP/per capita a tímtéž ukazatelem ostatních zemí.

53 Viz Aiginger, K.: „Copying the US or developing a New European Model - policy strategies of successful European contries in the 1990s.“ ECE/OSN seminář zabývající se „Konkurenceschopností a ekonomickým růstem v ECE-regionu“, Geneva II./2004. 
Tab. č. 6: Rozdíly v ukazatelích ekonomické výkonnosti tří skandinávských a tří kontinentálních členských států EU

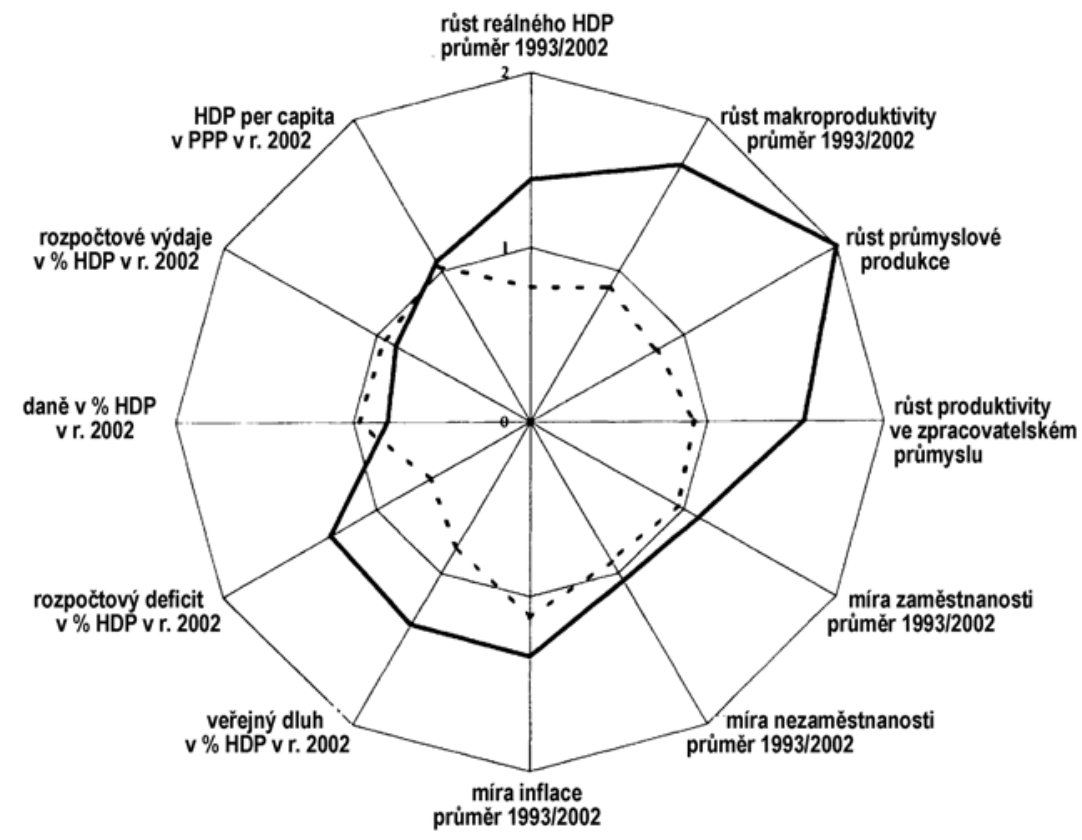

Dánsko, Švédsko, Finsko

- - - - Francie, Itálie, Německo

Pozn.: Hodnoty překračující vnitřní kruh reprezentují lepší než celo-unijní průměr.

Pramen: K. Aiginger, WIFO, Seminář ECE/OSN, II. 2004.

Ovšem i mezi ostatními státy EU přetrvávají dosud značné rozdíly jak v konkurenceschopnosti, tak i v celkové ekonomické výkonnosti. To lze ostatně vyrozumět i z následného přehledu nejdůležitějších makroekonomických ukazatelů charakterizujících tuto jejich výkonnost. 
Tab. č. 7: Př̀ehled ukazatelů konkurenceschopnosti a celkové ekonomické výkonnosti vybraných členských států EU (Vše průměr let 1993-2002, pokud není uvedeno jinak)

\begin{tabular}{|c|c|c|c|c|c|c|c|}
\hline & Belgie & Dánsko & Německo & Řecko & panělsko & Francie & Irsko \\
\hline růst reálného HDP 193-2002 & 2,0 & 2,5 & 1,3 & 2,8 & 2,8 & 1 , & 7,9 \\
\hline růst makroproduktivity & 1,4 & 1,8 & 1,1 & 2,1 & 1,0 & 1 , & 3,6 \\
\hline růst průmyslové produkce & 1,7 & 3,2 & 1,2 & 1,7 & 2,4 & 1 , & 13,1 \\
\hline růst produktivity v průmyslu & 3,1 & 3,4 & 3,2 & 3,7 & 3,4 & 0 , & 14,1 \\
\hline potenciální produkce & 2,1 & 2,2 & 1,7 & 2,6 & 2,9 & 2 , & 7,5 \\
\hline souhrnná faktorová produkce & 0,7 & 1,6 & 0,4 & 1,4 & 0,4 & 0 , & 3,6 \\
\hline míra zaměstnanosti & 57,5 & 76,2 & 67,7 & 54,1 & 61,1 & 60 , & 60,6 \\
\hline míra nezaměstnanosti & 8,6 & 5,8 & 8,4 & 10,0 & 15,4 & 10, & 9,0 \\
\hline míra inflace & 1, & 2,2 & 1,9 & 6,6 & 3,4 & 1 , & 2,7 \\
\hline $\begin{array}{l}\text { rozpočtový schodek v \% HDP } \\
\text { v roce } 2002\end{array}$ & $-0,1$ & $-1,8$ & 3,3 & 1,7 & 0,4 & 3 , & 1,7 \\
\hline veřejný dluh v \% HDP, 2002 & 105,3 & 45,2 & 60,8 & 97,8 & 54,0 & 59 , & 33,3 \\
\hline daně v \% HDP v 2002 & 50,1 & 57,1 & 45,3 & 44,7 & 39,3 & 50, & 32,6 \\
\hline \multirow[t]{2}{*}{$\begin{array}{l}\text { HDP per capita v } 2002 \\
\text { PPP v } 1000 \text { Euro }\end{array}$} & 26,1 & 27,2 & 24,6 & 15,9 & 20,2 & 24,5 & 29,3 \\
\hline & Itálie $\mathrm{I}$ & Nizozemí & Rakousko & Portugalsko & Finsko & Švédsko & $\begin{array}{l}\text { Velká } \\
\text { Británie }\end{array}$ \\
\hline růst reálného HDP 193-2002 & 1,6 & 2,7 & 2,0 & 2,5 & 3,3 & 2,9 & 2,8 \\
\hline růst makroproduktivity & 1,3 & 1,1 & 1,7 & 1,7 & 2,5 & 2,7 & 1,9 \\
\hline růst průmyslové produkce & 1,4 & 1,5 & 4,2 & 2,5 & 6,1 & 3,8 & 0,9 \\
\hline růst produktivity v průmyslu & $-0,2$ & 1,9 & 4,7 & 3,6 & 7,2 & 2,8 & 1,4 \\
\hline potenciální produkce & 1,6 & 2,8 & 2,2 & 2,8 & 2,7 & 2,4 & 2,5 \\
\hline souhrnná faktorová produkce & 0,8 & 0,9 & 0,8 & 0,7 & 2,7 & 2,4 & 1,6 \\
\hline míra zaměstnanosti & 56,8 & 71,3 & 72,9 & 69,0 & 63,2 & 73,2 & 74,9 \\
\hline míra nezaměstnanosti & 10,8 & 4,5 & 4,1 & 5,7 & 12,5 & 7,7 & 7,1 \\
\hline míra inflace & 3,1 & 2,6 & 2,0 & 3,7 & 1,6 & 1,6 & 2,4 \\
\hline $\begin{array}{l}\text { rozpočtový schodek v \% HDP } \\
\text { v roce } 2002\end{array}$ & 2,3 & 1,5 & 0,6 & 3,0 & $-4,4$ & $-0,8$ & 1,3 \\
\hline veřejný dluh v \% HDP, 2002 & 106,7 & 52,6 & 67,6 & 58,1 & 42,7 & 52,4 & 38,4 \\
\hline daně v \% HDP v 2002 & 45,2 & 45,9 & 51,3 & 43,2 & 53,7 & 59,1 & 39,4 \\
\hline $\begin{array}{l}\text { HDP per capita v } 2002 \\
\text { PPP v } 1000 \text { Euro }\end{array}$ & 24,5 & 27,0 & 26,4 & 16,6 & 24,4 & 24,3 & 24,7 \\
\hline
\end{tabular}

Pramen: K. Aiginger, WIFO, Seminář ECE/OSN, II. 2004.

O umírnění těchto rozdílů ve výkonnosti a konkurenceschopnosti jednotlivých členských států usiluje strukturální a kohezní politika Evropské unie již od jejího vzniku. S přechodem těchto států na „znalostně fundovaný“ typ ekonomického růstu se však výrazně rozšiřuje instrumentář použitelný $\mathrm{k}$ tomuto účelu. K němu náleží především výrazné navýšení prostředků delimitovaných v rámci centrálního rozpočtu EU na financování základního výzkumu a na rozvoj vědecko-technické součinnosti výzkumných pracovišt členských 
států ${ }^{54}$, jakož i předvídané rozšíření celoevropských informačních sítí. Náleží k němu však i předvídané zahájení nových projektů tzv. „předkonkurenčního výzkumu“ “55, jakož i rozšíření domácích výzkumných kapacit, jež by usnadnilo „překlíčování“ jeho výsledků do podoby bezprostředně využitelné podnikovou sférou jednotlivých členských států. Důležitou roli přitom zřejmě sehraje i lepší (a méně nákladné) zpřístupnění informací o inovacích a jiných významných technologických posunech, dosažených v kterémkoli členském státě EU, podnikové sféře všech ostatních členských států, nebot tím se může výrazně posílit inovační potenciál (zejména malých a středně velkých) podniků a napomáhat kromě toho i navazování kooperačních či subdodavatelských vztahů mezi nositeli a potenciálními uživateli těchto inovací.

Klíčový význam - nejen pro vznik „znalostně-fundovaného“ typu ekonomického růstu ve členských státech EU, nýbrž i pro posílení jejich technologické mezinárodní konkurenceschopnosti, bude mít zř̌ejmě zvýšený důraz kladený zde nadále na kontinuální zvyšování kvalifikace jejich obyvatelstva (na zavedení systému celoživotního vzdělávání), i na vytváření podmínek pro plné rozvinutî jeho invence a tvůrčích schopností. Je předvídáno též uplatnění řady dalších opatření usnadňujících zde urychlené podchycení a využití technologických vymožeností globálního významu, která budou napomáhat též zvýšení př́íspěvku zdejší výzkumné a podnikové sféry ke světovému technologickému rozvoji. Nepůjde přitom jen o to, posílit pozice evropských korporací mezi nejvýznamnějšími světovými nositeli inovací. Má-li se Evropská unie stát do roku 2010 nejkonkurenceschopnějším regionem světa ${ }^{56}$ musí zdejší výzkumná sféra dosahovat lepší výsledky než jsou ty, které vykazuje výzkum v druhých dvou regionech , triády“, přičemž zdejší podniky si budou muset osvojit podstatně vyšší inovační rytmus než je ten, jenž je zde dosud vžitý. Pro ilustraci značné náročnosti úkolu, jenž si Evropská unie v této oblasti (vědecko-technického rozvoje) vytkla postačí připomenout, že počty zde každoročně přihlašovaných patentů jsou dosud podstatně nižší než počty těch, které bývají přihlašovány v USA a v Japonsku, 57 že výskyt takovýchto patentů je zde prozatím nižší i v případě, provede-li se toto srovnání v přepočtu na 10000 obyvatel.

Zabezpečení tohoto náročného úkolu bude muset podniková sféra členských států EU napomáhat i tím, že přejde na uplatňování stejně rigorózních internacionalizačních strategií, jaké jsou v jiných ekonomicky vyspělých regionech světové ekonomiky uplatňovány již více než desítku let. Je podmíněno též provedením hlubokých zásahů do zdejších oborových struktur. Ty by měly vyústily v nahrazování výrob které se již stávají doménou podniků se sídlem v hospodářsky méně vyspělých zemích, i výroby výrobků, jejichž odbytové možnosti vykazují trvale nízkou dynamiku růstu, podstatně rentabilnějšími výrobami a aktivitami, po nichž narůstá poptávka zvýšenými tempy. Expertní odhady nasvědčují tomu, že - zejména ve velkých kontinentálních členských státech EU - připadá minimálně třetina stávajících průmyslových kapacit na uvedené prvé dva typy výrob, které lze jen stěží považovat za perspektivní. Opatření uplatňovaná zde na podporu rozvoje výrob a aktivit spadajících do kategorie vysokých technologií a na podporu přechodu zdejší podnikové sféry na aktivity s „,vyšší přidanou hodnotou“ - jimiž bude třeba tyto méně perspektivní výroby nahradit, - sice již přináší leckde pozoruhodné výsledky. Avšak vznik situace, kdy relativní váha takovýchto výrob a aktivit v rámci ekonomik uvedených členských států EU by převyšovala tu, která je dnes vžitá v druhých dvou regionech „triády“, se zde dosud nerýsuje. Urychlení těchto změn v jejich „specializačním profilu“ reprezentuje tudíž další z důležitých předpokladů pro brzké naplnění uvedeného cílového záměru Lisabonské strategie.

54 Viz např. „The 6th R\&D Framework programme of the European Community“.

55 Obdoby projektů typu RACE a ESPRIT, s jejichž pomocí se podařilo dosáhnout již v 80. letech nemalé posuny v př́islušných vědních disciplínách.

56 Viz Usnesení Lisabonské konference Rady Evropy, která se konala v březnu r. 2000.

57 Viz Reveue de Rexeco, Paris 1998. Též Fagerberg J., Godini M.: „Innovation and catching up“Oxford university press 2004 . 


\section{Literatura}

1. AGHION, Ph. - HOWIT, P.: Endogenous growth theory. Cambridge, MIT Press, 1998.

2. AIGINGER, K.: Copying the US or developing a New European Model - policy strategies of successful European countries in the 1990s. Spring seminar of the ECE/UN, 2004.

3. CHAMBERLIN, E. H. - ROBINSON, J.: The theory of monopolistic competition. Harvard University Press, 1933.

4. Economic Survey of Europe 2003/2, Geneva, 2003.

5. DUNNING, J. H.: International production and the Multanational enterprise. London, Allen \&Unvin, 1981.

6. FAGERBERG, J.: International Competitiveness. Economic Journal 98/1998.

7. FAGERBERG, J. - GOLDINI, M.: Innovation and catching up. Oxford University Press, 2004.

8. FAGERBERG, J. - KNELL, M. - SRHOLEC, M.: The competitiveness of nations: Economic growth in the ECE region. Spring seminar ECE/UN, 2004.

9. FREUDENBERG, M.: Composite Indicators of Country Performance: A critical Asessment. Paris, OECD, 2003.

10. HORVÁTH, G.: Competitiveness of regions and localities in Central and Eastern Europe. Spring seminar, ECE/UN, 2004.

11. KOX, H.: Business services and the Baumol disease. CPB Report 2002/2, Den Haag, 2002.

12. KRUGMAN, P.: Competitiveness: a dangerous obsession. Foreign Affairs No. 73/ 1994.

13. MYTELKA, L. K.: Competition, innovation and competitiveness in developing countries. Paris, OECD, 1999.

14. Rexeco: Conjoncture Economique et Financiére Paris. X.2003.

15. ROBINSON, J.: The economics of imperfect competition. London, 1963.

16. SCHUMPETER: Capitalism, Socialism and Democracy. Harper. N.Y., 1943.

17. SEREGHYOVÁ, J. - ZAFARPOUR, Sch.: Topical issues of international corporate networking in the globalising world economy Wirtschaftsuniversität Wien, 2004.

18. SEREGHYOVÁ, J.: Faktory ovlivňujicí konkurenční schopnost zpracovatelského průmyslu ČR pred a v prvých letech po jejím vstupu do EU. RASES, 2000.

19. SEREGHYOVÁ, J.: Konkurencia és koordinació a világpiacon. Budapest, Közgazdasági és jógi könivkiadó, 1974.

20. UNCTAD Handbook of statistics, IX. U.N. 2003.

21. WARWICK, K.: The role of governments in fostering competitiveness and growth. Spring seminar ECE/UN, 2004.

22. World economic outlook. IMF, Wash.DC. IX. 2003. 